\title{
Social Security Reform in the Presence of Informality
}

\author{
Kathleen McKiernan*
}

February 8, 2019

\begin{abstract}
As populations age, countries across the globe are dealing with the issue of how to fund retirement consumption for their workers. The design of Social Security programs is more difficult when the country also exhibits an informal economy in which workers avoid the taxation of the government and are not entitled to its benefits. In this paper, I study the example of Chile-a country that transitioned from a pay-as-you-go Social Security system to a system of private, individual retirement accounts in 1981 and also exhibits a significant informal sectorin order to quantify the transitional welfare impact of Social Security privatization when workers have the option to evade the public system through informality. I construct an OLG model which allows households to split working time between a taxed formal sector, an un-taxed informal sector, and home production. I find large long-run welfare gains of roughly 10 and 15 percent for low and high-productivity workers, respectively. However, these gains come at the expense of losses for two groups: those low-productivity workers who are retired at the time of the reform and those high-productivity workers within 5 years of retirement at the time of the reform. The presence of informality has two conflicting impacts: (1) including an outside option to formal work leads to smaller long-run transfers as government revenue is lower due to substitution from the formal to the informal sector, and (2) the privatization of the Social Security system causes wage growth that informal workers can receive without facing the distortions of any remaining taxation. Quantitative results indicate that these conflicting effects roughly cancel one another out and lead to long-run welfare gains that are similar to those in an economy without informality.
\end{abstract}

JEL Classification: E6, H55, E13

Keywords: Social Security, retirement, informal labor, Chile

${ }^{*}$ Department of Economics, Vanderbilt University, PMB 351819, 2301 Vanderbilt Place, Nashville, TN 37235. E-mail: kathleen.mckiernan@vanderbilt.edu. 


\section{Introduction}

As world populations age, many governments are dealing with the issue of how to provide retirement income for citizens. There is ample research that pay-as-you-go (PAYG) Social Security programs are unsustainable, especially in the presence of these aging populations. As the ratio of workers to retirees falls, the burden of the government to provide retirement consumption for the population increases. Previous work has shown there are long-run welfare gains from reforming from a pay-as-you-go Social Security program to a system of private, individual retirement accounts. However, this work also shows that these long-run gains are often financed by welfare losses for workers who live through the transition between the programs. As the economy transitions between the programs, the government loses payroll tax income from new workers. However, it must also compensate older workers and current retirees for prior contributions to the pay-as-you-go program.

This transition between PAYG and individual accounts and its welfare impact is influenced by how agents augment their savings, consumption, and-of particular importance for this study-labor choices in response to the policy change. The presence of outside options to working in the market is key in understanding the labor market response of workers. Specifically, the labor market response after a policy reform changes when households have the option to work informally. Recent estimates indicate that over 60 percent of the world's employed population works in the informal economy, and some areas of the globe may experience informality rates of nearly 90 percent. ${ }^{1}$ Due to the large size of this sector in many countries, understanding how policy changes interact with the size and behavior of this sector is important to understand possible impacts of such reforms.

Changes in the taxation and benefits associated with policy reforms change the incentives for formal and informal sector work. In particular, as taxes increase or the benefits that a worker is eligible for based on formal work decrease, the incentives for households to evade regulation and work informally increase. Therefore, as an economy transitions between a pay-as-you-go pension

\footnotetext{
${ }^{1}$ The International Labour Office finds a global informality rate 61.2 percent. They also measure that this rate is as high as 85.8 percent in Africa, 71.4 percent in Asia, 68.6 percent in the Arab states and 53.8 percent in the Americas.
} 
program and an individual account system and taxes and transfers adjust, the size of the informal economy changes. These changes have direct impact on the size of the tax base, the transfers workers are entitled to, and, thus, the government budget constraint. Therefore, movements in the size of the various labor sectors in response to a policy change can affect the long-run impact of the reform through impacts on the government budget.

In 1981, Chile became the first country to amend its PAYG Social Security system and begin the transition to a mandatory savings program consisting of private, individual retirement accounts. In the years that followed, this change has inspired other countries in Latin America, as well as countries throughout the world, to make changes to their own retirement systems. In the aftermath of the Chilean reform, ten other countries within Latin America took on reformed programs inspired by the new Chilean system. ${ }^{2}$ Additionally, countries all across the globe have reformed their Social Security systems ${ }^{3}$ to include individual retirement accounts. ${ }^{4}$ Many other countries, including the United States, however, have not moved away from their PAYG systems. The experience of Chile provides a case study of the impact of Social Security privatization. Additionally, the Chilean economy exhibits a significant informal economy. Therefore, the case of Chile provides a case study of not only Social Security privatization, but also the impact of such a reform in the presence of an informal economy.

To address this question, I build an overlapping generations model featuring three key features. First, I include age and productivity heterogeneity to study how the reform impacts welfare for different age groups and income levels. Second, I model the government policy after the specifics of the Chilean reform to isolate the impact of various aspects of the reform. Finally, I include a household decision to split working time between a taxed formal sector, an untaxed informal sector, and home production. This allows the policy reform to impact the fraction of workers in

\footnotetext{
${ }^{2}$ The Latin American countries that reformed to systems inspired by the Chilean model are: Argentina (1994), Bolivia (1997), Colombia (1993), Costa Rica (1995), Dominican Republic (2003), El Salvador (1998), Mexico (1997), Panama (2008), Peru (1993), and Uruguay (1996).

${ }^{3}$ Countries included in this category are: Bulgaria (2000), Croatia (2001), Denmark (2002), Estonia (2002), Hungary (1998), Kazakhstan (1998), Kosovo (2002), Latvia (2001), Nigeria (2001), Poland (1999), Russia (2002), Singapore (1997), Slovakia (2005), and Sweden (1999).

${ }^{4}$ These countries may not have systems that are entirely funded by private accounts, but at least part of their retirement funding programs include private, individual retirement accounts.
} 
each sector. The size of the sectors then changes the tax revenue collected by the government and the amount it must pay in the form of transfers.

Using micro-data for the Chilean economy, I estimate the parameters that discipline the relationship between home production and market labor as well as those that discipline the relationship between formal and informal labor supply. In addition to using this micro-data, I ensure that the model is consistent with various macroeconomic aggregates and use the government policy to construct historical series for the fiscal variables. By using this data, I can quantitatively measure the welfare impact of the transition between the pay-as-you-go and the privatized system of individual accounts.

In order to measure the welfare impact, I simulate the economy in two situations: one in which the reform occurs as it did historically, and a second as if the economy remained in the PAYG system from 1980. The results of this experiment show that long-run welfare gains are present due to the reform: manual laborers, who pay lower contribution rates and receive less generous pay-as-you-go pensions, experience gains of nearly 10 percent of lifetime consumption and employees and managers, who pay higher contribution rates and receive larger pensions prior to the reform, experience gains of roughly 15 percent. However, generations that live through the transition between the two programs experience welfare losses up to roughly 10 percent of remaining lifetime consumption. Manual laborers who are among the oldest generations at the time of the reform experience losses due to falling government transfers; employees and managers who are nearing retirement at the time of reform experience losses because the transitional policy pays them a smaller pension than they would have received under the pay-as-you-go program.

The inclusion of home production and informality lead to higher long-run welfare gains. However, these gains can be further decomposed into the portion that is caused by the inclusion of home production and those that are the result of informality. Similar to other research, I find that including only home production increases aggregate welfare gains from 4 percent to 11 percent because home production increases the elasticity of the labor supply. This leads the Social Security payroll tax to be more distortionary than in an economy without the option of home production. Therefore, 
the economy experiences larger long-run welfare gains when the payroll tax is removed through the reform.

Informality, on the other hand, causes two mechanisms which have opposite impacts on longrun welfare gains. These counteracting forces lead the inclusion of informality to have very little quantitative impact on the long-run welfare gains-aggregate welfare gains remain at 4 percent. The first effect is one which decreases the long-run welfare gains. Throughout the reform, households increase work in the informal sector relative to the formal sector. This leads to decreases in government revenue from labor income taxation. The decreased long-run transfers lead to lower welfare gains. The second effect increases long-run welfare gains. Throughout the transition path in which the reform occurs, wages increase. Because informality allows workers to take advantage of these higher wages without facing remaining income taxation, this effect leads to increased welfare.

The paper precedes as follows. Section 2 introduces the related literature. Section 3 discusses the background of the Chilean pension system before and after the reform. Section 4 describes the model. Section 5 details how parameters are estimated from the data. Section 6 presents the transitional results. Section 7 discusses how including informality and home production impacts the long-run results. Section 8 concludes.

\section{Related Literature}

The literature on privatization of Social Security systems is expansive. There are two areas of the Social Security reform literature most closely related to the work I present in this paper: welfare studies of Social Security reform and microeconomic studies on the impact of the Chilean reform.

Most papers involving the transition to a system of individual accounts in the United States come to a similar conclusion that there are positive long-run gains to switching from a pay-asyou-go system to an individual account system. These papers, however, disagree on whether it is possible to devise a system in which the welfare gains of future generations are not financed by welfare losses for those living through the transition. 
Huang, Imrohoroglu, and Sargent (1997) study a transition in which the government compensates the current generations by issuing debt. Although future taxes can be lowered, the taxes must remain high while the government pays off the debt. Kotlikoff, Smetters, and Walliser (1999) study many different policies and find that privatization has long-run gains that come with shortrun costs. Finally, studies such as Conesa and Krueger (1999), Nishiyama and Smetters (2007), Huggett and Parra (2010), and Imrohoroglu and Kitao (2012) find that adding uncertainty makes the transition to privatization even more challenging due to losses in the insurance provided by the Social Security program.

On the other hand, papers such as McGrattan and Prescott (2017) are able to find a system in which all agents experience welfare gains by flattening the tax schedule and removing the difference between average and marginal tax rates. Although they disagree on the transitional dynamics, all these papers document the long-term welfare gains of a reform in the United States.

In this paper, I study the long-term and transitional welfare impact of a reform in a Chilean economy that exhibits different properties than the economy in the United States, specifically the presence of large informal and home production sectors. Dotsey, Li, and Yang (2015) study how the inclusion of home production affects the transitional welfare results from Social Security reform. They find that the option to work at home increases labor supply elasticity and leaves the Social Security payroll tax more distortionary. Therefore, the inclusion of home production increases the long-run welfare gains from the reform. In my paper, the addition of informal work introduces another outside option for household hours which is present in the Chilean economy.

Feldstein (1998) presents a series of papers that discuss privatization of Social Security programs in various countries, including Chile. Edwards (1998) discusses the Chilean reform provides a background of the economy of Chile prior to and after the reform as well as transitional issues associated with the reform. ${ }^{5}$

In addition to this, much of the literature on the Chilean reform is concentrated on micro-level implications of the reform. Specifically, the literature focuses on details of the reform or on the

\footnotetext{
${ }^{5}$ Additional details of the Chilean system before and after the reform can be found in Kritzer $(2005,2008)$ and Kritzer, Kay, and Sinha (2011).
} 
labor force decisions of agents. Arenas de Mesa et. al. (2007) assesses the reformed system through studies of coverage, outcomes, and financial literacy 25 years after the reform; Acua and Iglesias (2001) address the impacts on similar variables after 20 years. Much work in this literature also comes in response to additional changes made to the Chilean system in $2008 .{ }^{6}$ Behrman et. al. (2011) analyzes the effects of the minimum pension levels on the household income, labor choices, health status, and spending behavior of the individuals. Additionally, Joubert (2010) and Joubert (2015) study the relationship between the design of the pension system and how it impacts the labor decision of the agent. Joubert and Todd (2011) and Arenas de Mesa and Montecinos (1999) extends the work of the prior two papers to study how the design impacts men and women differently. Specific to the economy of Chile, these papers, as well as Attanasio, Meghir, and Otero (2011), examine the impact that the pension changes have on the labor force participation in both the formal and the informal sectors of the economy. They find that increases in self-financed pension wealth negatively affects labor force participation in the formal sector. In this paper, I include features such as a two-sector labor market in a macroeconomic model to capture the labor decisions noted in previous work.

In addition to the literature on Social Security reform, I also contribute to the empirical literature on home production. I contribute by using micro-data to empirically measure the elasticities of substitution associated with informality and home production in Chile. A large literature, including Benhabib, Rogerson, and Wright (1991), has studied home production and the implications of including home production in economic models. Additionally, previous literature has also used data to measure the parameters that drive the interaction between market and home production. Using data from the United States, various papers such as Rupert, Rogerson, and Wright (1995), McGrattan, Rogerson, and Wright (1997), Chang and Schorfheide (2003), Fang and Zhu (2012), and Aguiar, Hurst, and Kararbarbounis (2013), estimate the elasticity of substitution between market

\footnotetext{
${ }^{6}$ The 2008 changes to the Social Security system were made in response to problems with agents, specifically women, not being able to accumulate a sufficient pension. The additional reforms made it possible for women to receive benefits without working 20 years, allowed her to be entitled to half of her husband's pension after a divorce, and gave a credit to a woman's for having a child. I will not consider the details of this reform when I analyze the impacts of the 1981 reform.
} 
and home production to be between 1.81 and 2.3. I use micro-data for Chile in order to estimate the same elasticities for the Chilean economy, while also extending the method to estimate a similar elasticity for informality.

\section{Model}

I use an overlapping generations model with heterogeneous households to analyze the impact of the 1981 Chilean Social Security reform. The economy is populated by households that differ in age and productivity. Productivity is constant throughout a household's lifetime. Time since entry into the workforce is called the age of the household and denoted by $j$. There is no survival uncertainty in the economy, and all households die at age $J$. All households retire at age $R, R<J$. A measure $\mu_{t}^{1, \varepsilon}$ enter as working age (age 1 ) households with skill level $\varepsilon$ at the beginning of period $t . \mu_{t}^{j, \varepsilon}$ is the measure of households of age $j$ and skill level $\varepsilon$ at time $t$.

The parameters $\mu_{t}^{1, \varepsilon}$ define the population dynamics. In particular,

$$
\mu_{t+1}^{1, \varepsilon}=\left(1+g_{t}\right) \mu_{t}^{1, \varepsilon}
$$

with $\sum_{\varepsilon} \mu_{0}^{1, \varepsilon}=1$. The growth rate of households entering the workforce is given by $g_{t}$. This parameter is assumed to be the same across productivity levels but is permitted to vary across time.

\subsection{State Vector}

The state vector of the economy, $S_{t}$, is defined as:

- $t$ : the time period

- $a^{j, \varepsilon}, \mu^{j, \varepsilon}$ : the assets of an age $j$ and skill level $\varepsilon$ household and the measure $\mu^{j, \varepsilon}$ of these households

- $\bar{y}^{j, \varepsilon}, \mu^{j, \varepsilon}$ : the average annual taxable earnings of an age $j$ and skill level $\varepsilon$ household and the measure $\mu^{j, \varepsilon}$ of these households 
- $K_{m}$ : the aggregate stock of market capital

- $B, G, \tau$ : the government fiscal policy variables (the series for debt, government spending, and taxes on consumption, labor, and firm profits and distributions)

\subsection{Household's Problem}

The value function of an agent of age $j \in\{1, \ldots, J\}$ with skill or productivity level $\varepsilon$ is given by:

$$
V_{j}\left(a_{t}, \bar{y}_{t}, S_{t} ; \varepsilon\right)=\max _{a_{t+1}, c_{m t}, d_{t}, h_{f t}, h_{i t}, h_{h t}} u\left(c_{t}, l_{t}\right)+\beta V_{j+1}\left(a_{t+1}, \bar{y}_{t+1}, S_{t+1} ; \varepsilon\right)
$$

Households of age $j$ and productivity $\varepsilon$ enter period $t$ with asset holdings $a_{t}$ and average taxable income $\bar{y}_{t}$. These households also face the aggregate state $S_{t}$. Utility takes consumption and leisure as inputs into the function $u(\cdot)$. These inputs are defined by:

$$
\begin{gathered}
c_{t}=h\left(c_{m t}, c_{h t}\right) \\
l_{t}=1-h_{m t}-h_{h t}
\end{gathered}
$$

Consumption is defined by a function, $h$, of consumption of a tradable market good, $c_{m t}$, and consumption of a non-trabable home produced good, $c_{h t}$. Leisure is a linear function of hours spent working in the market, $h_{m t}$, and hours spent working at home, $h_{h t}$. Additionally, market labor is a function of the time spent working in the formal sector and the time spent working in the informal sector of the economy.

$$
h_{m t}=\Gamma\left(h_{f t}, h_{i t}\right)
$$

The household maximizes utility subject to budget constraints for market and home produced goods. The budget constraint for market goods is given by the following:

$$
\left(1+\tau_{c t}\right)\left(c_{m t}+d_{t}\right)+a_{t+1}=\left(1+r_{t}\right) a_{t}+w_{t} \varepsilon\left(h_{f t}+h_{i t}\right)-T_{t}^{j}\left(w_{t} \varepsilon h_{f t}, \bar{y}_{t}\right)
$$


Households choose consumption of the market consumption good, $c_{m t}$, and spending on durable goods, $d_{t}$. The household pays a consumption tax, $\tau_{c t}$, on consumption of both goods. Additionally, the household chooses savings for period $t+1, a_{t+1}$. The income side of the market budget constraint is made up of three items. First, the household receives interest on the savings from the previous period, $\left(1+r_{t}\right) a_{t}$. Second, the household receives a wage, $w_{t}$, for hours worked in both the formal and informal sectors of the economy. Total labor income in these sectors is given by $w_{t} \varepsilon\left(h_{f t}+h_{i t}\right)$. Finally, the household pays taxes and receives transfers according to a net tax function, $T_{t}^{j}$. This net tax function is given by the following equation:

$$
T_{t}^{j}=\tau_{h t} w_{t} \varepsilon h_{f t}-\psi_{j}^{R}\left(\bar{y}_{t}\right)-\psi^{c}
$$

The household pays a labor income tax, $\tau_{h t}$, on the income received for work in the formal sector of the economy. It then receives a retirement transfer, $\psi^{R}\left(\bar{y}_{t}\right)$ which is dependent on the average taxable earnings in period $t$. Finally, the household receives a common transfer, $\psi^{C}$ which is independent of age, skill, and lifetime labor supply decisions. During working years, the value of the retirement transfer is 0 . During retirement, households do not work in the market. Therefore, labor tax paid during retirement is 0 and the function simplifies to only the transfers.

Spending on durable goods, $d_{t}$, from the market budget constraint and the hours spent working in the home production sector are used as inputs into the production of the non-tradable home produced good. The budget constraint for home production states that consumption of the home produced good must be equal to the output of the home production function, $g$.

$$
c_{h t}=g\left(d_{t}, h_{h t}\right)
$$

The individual states, $a_{t}$ and $\bar{y}_{t}$, evolve based on the choices of savings, $a_{t+1}$, and formal sector work, $h_{f t}$. Specifically, savings are set as the chosen asset holdings for period $t+1$ and average taxable income evolves based on the following equation: 


$$
\bar{y}_{t+1}= \begin{cases}\frac{(j-1) \bar{y}_{t}+w_{t} \varepsilon h_{f t}}{j} & , \text { if } j \leq R \\ \bar{y}_{t} & \text {,if } j>R\end{cases}
$$

The aggregate states of the economy evolve with a function, $G$, that is assumed to be known by the household.

$$
S_{t+1}=G\left(S_{t}\right)
$$

\subsection{Technology}

The production function for the market sector good is given as follows:

$$
Y_{t}=f\left(K_{m t}, H_{m t}\right) \text { where } H_{m t}=H_{f t}+H_{i t}
$$

Formal sector production uses aggregate market capital and aggregate market labor supply, where aggregate market labor supply is the sum of aggregate formal labor and aggregate informal labor. Additionally, capital evolves according to the following equation, where $\delta$ represents depreciation and $X_{m t}$ is investment in market capital.

$$
K_{m t+1}=(1-\delta) K_{m t}+X_{m t}
$$

Prices, consisting of the return on capital and the wage, are set equal to the marginal products of capital and labor, respectively, in the market sector.

$$
\begin{gathered}
r_{t}=f_{K}\left(K_{m t}, H_{f t}+H_{i t}\right)-\delta \\
w_{t}=f_{H}\left(K_{m t}, H_{f t}+H_{i t}\right)
\end{gathered}
$$

\subsection{Government}

Government policy is defined as a series of sequences, $\left\{\tau_{c t}, \tau_{p t}, \tau_{d t}, T_{t}^{j}(\cdot), B_{t}, G_{t}\right\}$ which represent various fiscal policy elements. $\tau_{c t}$ denotes a tax rate on consumption. $\tau_{p t}$ represents a tax on 
accounting profits of the firm. $\tau_{d t}$ is a tax on distributions of the firm.

In order to define the budget constraint of the government, profits and firm distributions must be defined. Accounting profits of the firm, $\Pi_{t}$, and the distributions of these firms, $\Delta_{t}$, are given by the following equations:

$$
\begin{aligned}
& \Pi_{t}=Y_{t}-w_{t}\left(H_{f t}+H_{i t}\right)-\delta K_{m t} \\
& \Delta_{t}=\left(1-\tau_{p t}\right) \Pi_{t}-K_{m t+1}+K_{m t}
\end{aligned}
$$

Additionally, $T_{t}^{j, \varepsilon}(\cdot)$ represents the net tax function from the household problem which combines the payroll tax, retirement transfers, and common transfers. $B_{t}$ denotes government debt, and $G_{t}$ represents government consumption of a pure public good.

The government budget constraint is defined as:

$$
B_{t+1}+\tau_{c t}\left(C_{m t}+D_{t}\right)+\tau_{p t} \Pi_{t}+\tau_{d t} \Delta_{t}+\sum_{j, \varepsilon} \mu_{t}^{j, \varepsilon} T_{t}^{j, \varepsilon}\left(w_{t} \varepsilon h_{f t}, \bar{y}_{t}\right)=\left(1+r_{t}\right) B_{t}+G_{t}
$$

On the revenue side of the government budget constraint are issuance of new debt, $B_{t+1}$, and collection of taxes. These taxes are the consumption tax on market consumption and durable spending, the profit tax on accounting profits of the firm, the distributions tax on the firm's distributions, and the outcome of the net tax function when aggregated over the heterogeneous households alive in any period $t$. The budget constraint requires that revenue must be equal to government spending. Total government spending is the sum of interest paid on the debt from the previous period, $\left(1+r_{t}\right) B_{t}$ and government spending on a pure public good, $G_{t}$.

I assume that government debt and government spending are a percentage of output. Specifically,

$$
\begin{aligned}
B_{t} & =\phi_{B} Y_{t} \\
G_{t} & =\phi_{G} Y_{t}
\end{aligned}
$$

\subsection{Equilibrium}

An equilibrium in this economy is given by government policies, prices, and allocations such that: ${ }^{7}$

\footnotetext{
${ }^{7}$ Detailed equilibrium definition is given in the technical appendix.
} 
1. Given the government policies, interest rate, and wage rate, the value functions and allocations solve the household's maximization problem given the state variables

2. The price of each factor is equal to its marginal product

3. The government budget constraint holds in each period

4. All markets clear

\section{Social Security in Chile}

\subsection{Before the 1981 Reform}

The Chilean Social Security reform of 1981 replaced a pay-as-you-go system with a retirement age of 65 for men and 60 for women. This old system (called the INP system ${ }^{8}$ ) was comprised of many different pension institutions. Each of these institutions, known as Cajas de Prevision, covered the pensions for a subset of the population. Because each of the Cajas de Prevision was independent, the pensions were dependent on the employer. Each institution had its own contribution and indexation rates, benefit levels, and requirements for retirement. However, 94 percent of the population was covered under one of three main systems for salaried workers (whitecollar), manual laborers (blue-collar), and government employees. Other smaller funds had fewer than 1,000 members each. The agents were required to contribute to the system, through a payroll tax, for 20 years before they were eligible for pension benefits. ${ }^{9}$

Although each pension institution had different a indexation rate for calculating benefits, all institutions calculated benefits as a percentage of average earnings. Average earnings were calculated over the five years prior to retirement. This was constant over all funds; retirees could receive different percentages of this average depending on the institution. Due to the reform, the system was heavily simplified by introducing a single method of retirement funding for everyone. ${ }^{10}$

\footnotetext{
${ }^{8} \mathrm{INP}=$ Instituto de Normalizacion Previsional

${ }^{9}$ Agents were not required to contribute for 20 consecutive years. Rather agents must contribute for a total of 80 quarters prior to retirement in order to receive the Social Security benefits.

${ }^{10}$ Government and military workers have their own pension system and are exempt from enrolling in the AFP system.
} 


\subsection{After the 1981 Reform}

The new system, called the AFP system ${ }^{11}$, began in May 1981. The INP system was immediately closed to new entrants, and all workers who entered the workforce after this date were automatically enrolled in the new AFP system. Workers who had already made contributions to the INP system were given five years to decide whether they would switch to the AFP program. In order to induce workers from the old system to switch to the new system, workers were offered two things. First, workers were offered a one time 17 percent increase in net income. ${ }^{12}$ Second, those who switched were given a recognition bond to represent the contributions they had made to the old INP system. These inducements encouraged 90 percent of the workers covered under the old system to switch to the reformed system by 1986 .

After the reform occurred in 1981, the rules changed. The payroll tax is eliminated, but the workers are now required to contribute 10 percent of monthly earnings up to a ceiling. ${ }^{13}$ These contributions are tax-deferred and difficult to draw from before retirement. ${ }^{14}$ In addition to the mandatory savings, Chilean workers are required to contribute 7 percent of monthly earnings for health insurance and around 3 percent of monthly earnings for survivor and disability insurance as well as administrative fees. The worker can choose to invest his funds in one of the AFP firms who manage and invest the contributions. These firms compete amongst themselves. Those that do not perform sufficiently for the workers' funds are dissolved.

Specifically, the Chilean government imposes a lower and upper limit on the returns an AFP must pay its members. If a fund over-performs ${ }^{15}$, excess returns are placed in a profitability reserve.

\footnotetext{
${ }^{11} \mathrm{AFP}=$ Administradoras de Fondos de Pensiones

${ }^{12}$ The Chilean government mandated firms to give this income raise to workers who switched. Firms were willing to give such an increase as the employer contribution included in the old system was removed when moving to the reformed system. High inflation during this time raises questions on whether this caused any real increase in worker income.

${ }^{13}$ The ceiling for monthly contributions is 66 Unidades de Fomento (UF). Unidades de Fomento is a Chilean unit of account constantly adjusted to inflation so that the value of the UF remains constant or nearly constant during times of low inflation. As of 2015, 66 UF is equivalent to nearly $\$ 2500$. Agents also have the option to contribute up to an additional 48 UF tax-deferred if they choose.

${ }^{14}$ There are very strict restrictions on withdrawing funds from the account before retirement. These restrictions are more restrictive than those on US $401 \mathrm{~K}$ plans.

${ }^{15}$ Over-performing, on the hand, occurs if the fund achieves a return of 50 percent or 2 percentage points higher than the average across AFPs. Under-performing in this context is if the AFP fund achieves a return of 50 percent of
} 
If the fund then under-performs in future years, reserves ${ }^{16}$ are used to make up the difference between the actual return and the minimum return guaranteed by the state. If the AFP cannot meet the requirements with its reserves, it is liquidated, the government makes up the difference between the return and the minimum guarantee, and all contributors transfer their funds to another AFP.

Individuals can access their retirement savings funds at age 65 for men and age 60 for women. The law permits early retirement if the worker has accumulated an amount greater than 110 percent of the minimum pension guaranteed by the government. The pension must be greater than 50 percent of the average of taxable income over the last ten years. Non-contributory retirement income is available either through a welfare pension that is independent of contribution history or through a minimum pension guarantee that is available only to workers who contributed sufficiently but whose funds were not able to fund a higher pension. All workers over age 65 are eligible for a welfare pension, called PASIS. The PASIS pension is around one-third of the minimum wages. If an agent has made more than 20 years of contributions, he is eligible for the minimum pension guarantee (MPG). This pension is about twice the PASIS pension.

\section{Parameters}

I will use data and prior literature to set three categories of parameters. First, the details of the pension reform policy and aggregate data on government revenue and spending is used to set government policy parameters and fiscal policy time series. Second, survey data is used to estimate the parameters governing home production and market labor supply decisions. Finally, other model parameters will be internally calibrated to aggregate data or set based on prior literature.

2 percentage points lower than the average across AFPs.

${ }^{16}$ In addition to the profitability reserve, AFPs must hold an investment reserve of that amounts to at least 1 percent of the total value of the fund and is invested in a portfolio that exactly mimics that of the fund. 


\subsection{Government Policy Parameters and Fiscal Series}

Prior to 1981, pension benefits were dependent on employment. Different types of workers faced different rules in regards to contribution rates and indexation rates. The two largest funds were those covering manual laborers and salaried workers. Based on this, I choose to model the details of the pension programs for two groups: manual laborers and salaried workers. The program for manual laborers is known as Servicio de Seguro Social (SSS), and the program for salaried workers is called Caja de Empleados Particulares (EMPART). In this work, manual laborers are covered under SSS while employees and managers are assumed to receive a salary and are covered by EMPART. ${ }^{17}$ In this paper I use three productivity types. These groups are defined as manual laborers, employees, and managers.

\section{Contribution Rates}

Prior to the reform, each of the two main systems had differing contribution rates for both employees and employers. Employees paid a percentage of earnings and employers contributed a percentage of the payroll bill to the pension fund. These contribution rates are shown in Table 1. Prior to the reform, blue-collar employees pay 7.25 percent of income to pension funds; employers contribute 15.95 percent of payroll. Under the program for white-collar workers, employees contribute 16.67 percent and employers contribute 10.83 percent. I assume that the employer contributions are passed through to workers and are combined into the payroll tax of the agent. After the reform occurred, agents who switched between the programs faced different tax rates from those who chose to stay under the pay-as-you-go program. Those who switched now only pay the tax used for survivor and disability insurance. This rate is 7 percent. Workers who stayed under the previous program, on the other hand, now faced higher tax rates. Blue-collar workers now must contribute 18.9 percent to the pension program while white-collar workers contribute 19.9 percent.

\section{Retirement Transfers}

\footnotetext{
${ }^{17}$ The data does not contain a question for which program a worker is covered by. I set these groups based on their occupation. While not a perfect translation, workers who identify as obreros will be considered manual laborers, those who respond empleados are considered employees, and those who answer empleadores are defined as managers.
} 
The form of the Social Security transfers received by the retired households will be dependent on the time period in question, whether the cohort was in the labor force at the time of the reform, and whether a household chooses to switch between the programs. This work assumes that all agents immediately switch to the individual account system. ${ }^{18}$ Therefore, the government transfers will be dependent only on the time period and the birth-year cohort of the household. Note that for any worker who is not of retirement age, $\psi^{R}=0$. Consider the transfers for retired workers in three different cases:

$$
\psi^{R}= \begin{cases}\zeta^{\varepsilon} \bar{y}_{t} & \text { Before the reform } \\ \frac{1}{J-R}\left[0.8 \bar{y}_{t}\left(\frac{t^{*}-t_{0}}{35}\right) v_{G} v_{A}(1.04)^{R-t^{*}}\right] & \text { Cohorts who entered the workforce } \\ \max \left\{0, \underline{c}-\left(\frac{R-1}{J-R}\right) *\left(0.1 \bar{y}_{t}\right)\right\} & \text { prior to the reform and switched } \\ & \text { Cohorts who entered the workforce } \\ & \text { after to the reform and year is prior to 2008 }\end{cases}
$$

Case 1: Prior to the reform

$$
\zeta^{\varepsilon} \bar{y}_{t}
$$

Under the pay-as-you-go Social Security system, agents are entitled to some percentage $\zeta^{\varepsilon}$, known as the indexation rate, of working-age income. This working-age income is calculated as the average income over the five years prior to retirement. ${ }^{19}$ Additionally, the indexation rate varies by profession, or skill in the model. SSS entitles manual laborer households to receive up to 70 percent of pensionable wages during retirement. ${ }^{20}$ EMPART gives employees and managers 100 percent of pensionable wages during retirement. ${ }^{21}$

\footnotetext{
${ }^{18}$ This is a reasonable assumption as 77 percent of workers covered until the PAYG system had chosen to switch to the new system by 1983; 90 percent of workers had chosen to switch by 1986. The case in which no one switches is shown in the technical appendix.

${ }^{19}$ Rather than using average income for the 5 years prior to retirement, I use an average over total working life in order to calculate benefits. I do this in order to simplify the transfers through the transition. By using this, I can use the same state variable to calculate transfer under all three cases.

${ }^{20}$ Under SSS, agents receive 50 percent of pensionable wages after 10 years of contributions to the program and 1 percent for each year of contributions over 10 years. This is capped at 70 percent of pensionable wages. Under this system, pensionable salary is calculated as the average of salary for the 5 years prior to retirement. This value is not indexed to inflation.

${ }^{21}$ Under EMPART, pensionable wages are calculated as the average of the wages for the five years prior to retirement where the most recent two years are indexed to inflation.
} 


$$
\zeta^{\varepsilon}= \begin{cases}0.70 & , \text { SSS } \\ 1.00 & , \text { EMPART }\end{cases}
$$

Note that this case would also cover those workers who entered the workforce prior to the reform but chose not the switch to the new program.

Case 2: Agents who entered the workforce before the reform and switched to the new program

$$
\frac{1}{J-R}\left[0.8 \bar{y}\left(\frac{t^{*}-t_{0}}{35}\right) v_{G} v_{A}(1.04)^{R-t^{*}}\right]
$$

Households who entered the workforce prior to the reform and chose to change to the new system receive transfers that represent the recognition bond. The value of this bond is given by the formula above. $t^{*}$ represents the time period in which the reform occurred (1981), and $t_{0}$ represents the year a particular agent entered the workforce. This recognition bond represents the Social Security payouts the agent should receive for the contributions that had already been made. This formula is calculated from four elements: 80 percent of pensionable salaries ${ }^{22}$, a correction for years of contributions, a correction for age and gender, and interest for the time between when the reform occurs and the household retires.

It is assumed that 35 years is the number of contribution needed to receive a normal pension. Therefore, the calculation of 80 percent of the average earnings for the twelve months prior to June 1979 is multiplied by the ratio of the years contributed to 35 .

The value of the recognition bond is then also corrected for both age and gender. $v_{G}$ corrects for gender. This value is 10.35 for men and 11.36 for women. I use a value of $11 . v_{A}$ varies based on both the age and gender of the agent. ${ }^{23}$ It varies between 1 and 1.11 for men and 1 and 1.31 for women. ${ }^{24}$ I will use a value of 1.15 for the family. ${ }^{25}$

\footnotetext{
${ }^{22}$ In the calculation of the recognition bond, pensionable salaries are calculated based on all earnings received prior to April 1979.

${ }^{23}$ This correction is set so that men who enter the new system at age 61 or older and women who enter at age 42 or older receive additional benefit.

${ }^{24}$ In 1980, there were no pension benefits for married couples. Therefore, I model the pension of an agent rather than the pension of a household.

${ }^{25}$ Future versions of the paper will contain sensitivity on how the value of this parameter changes results.
} 
The recognition bond received a 4 percent real return. Therefore, interest on the bond is compounded based on the years between the reform and the time period that the agent retires. This interest is added to the amount the agent receives.

This calculation gives the total sum of money received by the worker as a representation of the previous contributions to the pay-as-you-go system. I assume that an equal amount is paid out to the retiree in each period of retirement. Therefore, this total is divided by the number of years spent in retirement, $J-R$.

Case 3: Agents who entered the workforce after the reform

All agents who entered the workforce after the reform occurred are immediately enrolled in the new system. Under this system, retirement consumption is funded through individual savings. The government, however, guarantees a minimum pension if accumulated savings are not sufficient. If agents accumulate sufficient assets, transfers in this case are 0 . This policy is top-up in construction. This means that if savings are not sufficient to fund a higher pension, government transfers are equal to the difference between the savings of the agent and the minimum guaranteed by the government. The minimum pension guarantee is around two-thirds the minimum wage. ${ }^{26}$

$$
\max \left\{0, \underline{c}-\left(\frac{R-1}{J-R}\right) *\left(0.1 \bar{y}_{t}\right)\right\}
$$

The second term in the max function represents the amount that would be received if savings cannot fund a sufficient pension. $\underline{c}$ represents the lower bound the government set on retirement consumption. $\left(\frac{R-1}{J-R}\right) *\left(0.1 \bar{y}_{t}\right)$ represents the retirement savings of the household split equally between the years of retirement. I assume all agents save the 10 percent of wages required by law. This 10 percent of taxable income is multiplied by the number of years spent working, $R-1$, and divided by the years of retirement, $J-R$.

The lower bound of consumption, $\underline{c}$, is set based upon the government policy. I will set this value as a percentage of the average wage. ${ }^{27}$ In particular, the minimum pension guarantee is set

\footnotetext{
${ }^{26}$ In 1980, minimum wage was around 48,000 Chilean pesos.

${ }^{27}$ James, Estelle, and Iglesias (2007) find that the minimum pension guarantee (MPG) provided by the government
} 
to be 25 percent of the average wage for workers between the ages of 65 and 70, 27 percent of the average wage for workers between the ages of 70 and 75, and 29 percent of the average wage for workers over the age of 75 .

\section{Fiscal Variables}

Additionally, time series for government debt, government spending on defense, aggregate spending on social programs and consumption taxes are calculated from the data. ${ }^{28}$ Future values for these variables are calculated in two ways. first, those between the data and 2020 are fit using a time trend from the 10 years prior. The series, as a percentage of GNP, are assumed to be constant after 2020 .

\subsection{Home Production and Market Labor Supply Parameters}

I choose CES functions to represent the relationships for the home production and market labor supply parameters, $h(\cdot), \Gamma(\cdot)$, and $g(\cdot)$. Specifically,

$$
\begin{gathered}
c_{t}=h\left(c_{m t}, c_{h t}\right)=\left\{a_{1} c_{m t}^{b_{1}}+\left(1-a_{1}\right) c_{h t}^{b_{1}}\right\}^{1 / b_{1}} \\
h_{m t}=\Gamma\left(h_{f t}, h_{i t}\right)=\left\{a_{2} h_{f t}^{b_{2}}+\left(1-a_{2}\right) h_{i t}^{b_{2}}\right\}^{1 / b_{2}} \\
c_{h t}=g\left(d_{t}, h_{h t}\right)=\left\{a_{3} d_{t}^{b_{3}}+\left(1-a_{3}\right) h_{h t}^{b_{3}}\right\}^{1 / b_{3}}
\end{gathered}
$$

\subsubsection{Data and Sample}

Data for this estimation comes from two sources. First is Encuesta Nacional Sobre el Uso del Tiempo (ENUT) - a time use survey that contains a representative sample of the Chilean population. The 2015 survey is used in the analysis. The second data source used is the Encuesta de after the 1981 reform is between 25 and 29 percent of the average wage.

${ }^{28}$ More discussion on the time series for these government policy variables is included in the technical appendix. 
Protección Social ${ }^{29}$ (EPS). This is a longitudinal study which contains a representative sample of the national population. The 2004, 2006, and 2009 waves are used in the estimation. ${ }^{30}$ The data from the first survey, ENUT, is used in order to estimate how the hours of home work vary across observable characteristics which are present in both data sets. The results are then used to impute values of home work for individuals present in the EPS. The EPS data with imputed home work is then used to estimate the parameters $a_{1}, b_{1}, a_{2}, b_{2}, a_{3}, b_{3}$.

ENUT is a two-part survey. The first part is a household questionnaire containing demographic and socioeconomic information for the individual and the household. The second part of the survey is a time use questionnaire in which the respondent answers the amount of time spent on various activities in the last day. They are surveyed on one week day and one weekend day. My sample contains only individuals who responded to both the household questionnaire and the time use questionnaire. 21,960 individuals responded to both questionnaires. The final sample used is the subset of these respondents who are between the age of 25 and 65 who reported that nothing out of the ordinary occurred in the last week. The final sample contains 13,614 individual. This comes out to 62 percent of the the total sample.

The estimation sample from the EPS is constructed as a combination of the household responses from the 2004, 2006, and 2009 waves of the survey. ${ }^{31}$ A sample from each cross-section is first constructed. The final sample is created as a panel of households observed in at least two consecutive cross-sections. The three waves of the survey contain 14,856; 14,836; and 10,347 households respectively. The final sample for each year cross-section contains the responses for households in which the head of the household is working age ${ }^{32}$, works at least 30 hours per week

\footnotetext{
${ }^{29}$ Esta investigación utilizó información de la Encuesta de Protección Social. El autor agradece a la Subsecretaría de Previsión social, propietaria intelectual de la Encuesta, la autorización para usar la Base de Datos Innominada. Todos los resultados del estudio son de responsabilidad del autor y en nada comprometen a dicha Subsecretaría.

This research used information from the Social Protection Survey. The author thanks the Subsecretary of Social Prevision, the intellectual owner of the Survey, for the authorization to use the anonymous database. All the results of the study are the responsibility of the author and not of the aforementioned Subsecretary.

${ }^{30}$ The 2002 waves of the EPS is representative of only those individuals and household that are affiliated with the pension system. As of the 2004 waves, the survey was corrected to be representative of the population as a whole. I choose to use the nationally representative 2004, 2006, and 2009 waves as I want to consider the impact of informal laborers who are not necessarily affiliated with the pension system.

${ }^{31}$ Results from the estimation of the parameters of cross-sections from each year are also included in the appendix.

${ }^{32}$ By excluding agents who are not working age, I also remove agents who receive minimum pensions from the
} 
for at least 40 weeks per year, and does not receive a welfare pension from the government. This assumption is made as data on income support programs and welfare pensions and their interaction with the labor supply is not included. The final sample also includes all households with non-zero spending on non-durable and durable consumption. The final samples for three waves contain 8,313 observations, 14,836 observations, and 10,347 observations, respectively. These final samples for each year are pooled together for the estimation.

\subsubsection{Estimation and Results}

The following regression equations are derived from the first order conditions of structural model. This procedure builds upon the methodology used in the literature related to home production. ${ }^{33}$ The extension here includes the derivation of an equation relating formal labor supply to informal labor supply. The results of estimating these equations gives an understanding of the how households substitute between various decisions. At the same time, estimation of these equations gives a relation between the data and the parameters of the structural model. These equations are derived from three marginal conditions of the structural model: the relationship between the marginal utility of formal labor and informal labor, the relationship between the marginal utility from home hours and durable spending, and the relationship between the marginal utility gained from market consumption and durable spending. ${ }^{34}$ Households substitute between decisions based on relative prices and the substitutability of other decisions.

$$
\ln \left[\frac{h_{f}}{h_{i}}\right]=\beta_{0}+\beta_{1} \ln \left[\left(1-\tau_{h}\right)+\frac{\partial \psi^{R}}{\partial h_{f}}\right]+\varepsilon_{1}
$$

where $\beta_{0}=\frac{1}{b_{2}-1} \ln \left[\frac{1-a_{2}}{a_{2}}\right]$ and $\beta_{1}=\frac{1}{b_{2}-1}$

$$
\ln \left[\frac{h_{h}}{d}\right]=\beta_{2}+\beta_{3} \ln \left[\frac{\left(1-\tau_{h}\right) w \varepsilon}{\left(1+\tau_{c}\right)}\right]+\beta_{4} \ln \left[1+\frac{1-a_{2}}{a_{2}}\left(\frac{h_{i}}{h_{f}}\right)^{b_{2}}\right]+\varepsilon_{2}
$$

government. This is done because data on this pension transfer and its impact on labor supply is not included in the analysis.

${ }^{33}$ Papers in this literature include Rupert, Rogerson, and Wright (1994) and Fang and Zhu (2012).

${ }^{34}$ Derivation of these regression equations is described in the technical appendix. 
where $\beta_{2}=\frac{1}{b_{3}-1} \ln \left[\frac{a_{3}}{1-a_{3}}\right]-\frac{1}{b_{2}\left(b_{3}-1\right)} \ln \left[a_{2}\right], \beta_{3}=\frac{1}{b_{3}-1}$, and $\beta_{4}=\frac{b_{2}-1}{b_{2}\left(b_{3}-1\right)}$

$$
\ln \left[\frac{c_{m}}{d}\right]=\beta_{5}+\beta_{6} \ln \left[1+\frac{1-a_{3}}{a_{3}}\left(\frac{h_{h}}{d}\right)^{b_{3}}\right]+\varepsilon_{3}
$$

where $\beta_{5}=\frac{1}{b_{1}-1} \ln \left[\frac{1-a_{1}}{a_{1}}\right]+\frac{b_{1}}{b_{3}\left(b_{1}-1\right)} \ln \left[a_{2}\right]$ and $\beta_{6}=\frac{b_{2}-b_{3}}{b_{3}\left(b_{1}-1\right)}$

A few issues must be discussed in the estimation procedure. First, the log-linear structure of the regressions limits the estimation to observations without corner solutions. These corner solutions can occur in both labor supply and consumption decisions. The number of corner solution in consumption (durable and non-durable) and home work hours are minimized by the way in which the data is constructed. First, zero spending on consumption is minimized by aggregating the data to the household level and including housing spending in the measure of durable consumption. Also, because hours of home work is imputed based on the observables available there are no corner solutions in home work hours. For these reasons, I am not concerned with bias caused by the omission of corner solutions in these equations. However, only 25 percent of households in 2004, 22 percent in 2006, and 16 percent of households in 2009 have positive number of annual hours in both the formal and informal sectors. Therefore, there is reason to be concerned about bias caused by the exclusion of the corners in this first regression. While inclusion of these corner solutions changes the estimates, the magnitude of these changes is minimal.

Another issue of the estimation that must be considered is whether the independent variables are correlated with the error term. For example, it is reasonable to believe that the labor income tax rate is correlated with the amount of work in the formal sector but also things such as education level. I deal with this issue is two ways: by adding controls for household level effects that may be contributing and using instrumental variables. In the regression involving the substitutability of formality and informality, I control for age, industry, region, and lagged formal hours. In the regressions involving home production, I follow home production literature and use an instrumental variables approach. The instruments used are: age of the head of household, age of the head of household squared, education of the head of household, age of the spouse, age of the spouse squared, education of the spouse, a dummy for whether the household resides in Santiago, and 
lagged values of formal work, durable spending, and market consumption. ${ }^{35}$ These instruments based upon the instruments used by Rupert, Rogerson, and Wright (1994). ${ }^{36}$

Table 2 shows the structural parameters constructed from these regression results. Formal and informal hours have roughly equal weight in market hours and the two types of work are nearly perfect substitutes. ${ }^{37}$ Home production is produced using nearly equal amounts durable spending and home hours while total consumption is weighted to home consumption. The elasticities of substitution between durable spending and home hours in home production and market consumption and home consumption in total consumption show that these inputs are much less substitutable than formal and informal hours are in market hours. The standard errors for estimates on the parameters for total consumption and market hours are low, indicating precise estimate for the parameters. Standard errors for the home production function, however, are quite large. While these parameters may not be precisely estimated from the data, the values are comparable to estimates found in studies of the United States. ${ }^{38}$ Therefore, this should not bias my results.

\subsection{Other Parameters}

The remaining parameters are either set outside the model based on previous literature and data or internally calibrated to match macroeconomic aggregates. These parameters are shown in Table 3.

\subsubsection{Parameters Set Outside the Model}

\section{Coefficient of Relative Risk Aversion}

The utility function is represented by a CRRA function.

\footnotetext{
${ }^{35}$ By including the age of spouse and education of spouse as instruments in the IV regression, the sample excludes households consisting of a single member or households with only one parent. 69 percent of population in 2004 was in a married or co-habitating relationship.

${ }^{36}$ Due to differences in the data and modeling, these are not the exact instruments used in Rupert, Rogerson, and Wright (1994). They use age of husband, age of husband squared, age of wife, age of wife squared, the wife's education, lagged consumption, lagged wife's home work, and dummies for whether living in a SMSA, whether covered by a union, and whether living in the South in order to estimate the home production elasticity.

${ }^{37}$ The elasticity of substitution in these equations is given by $\varepsilon=\frac{1}{1-b_{i}}$. A value of $b_{i}=1$ is associated with perfect substitutes, $b_{i}=0$ is Cobb-Douglas, and $b_{i}=-\infty$ is associated with perfect complements.

${ }^{38}$ I performed the same estimation procedure on data for the United States. In this exercise, I find estimates in the ranges of the estimates found by other researchers. Details on this test is in the technical appendix.
} 


$$
U(c, l)=\frac{\left(c^{\gamma} l^{1-\gamma}\right)^{1-\sigma}-1}{1-\sigma}
$$

In order to set a value for the coefficient of relative risk aversion, I look to other papers which use a utility function that is non-separable between consumption and leisure as well as papers in the home production literature. In these literatures, $\sigma$ is usually set between 1.5 and $4^{39}$. I set $\sigma=2$ in the analysis that follows.

\section{Production Parameters}

I choose a Cobb-Douglas function for the market production function:

$$
Y_{t}=\left(K_{m t}\right)^{\alpha}\left(H_{f t}+H_{i t}\right)^{1-\alpha}
$$

The weight of capital in market consumption, $\alpha$, and the depreciation rate of capital, $\delta$, are also set outside the model. In accordance to other literature, I set $\alpha=0.33$ and $\delta=0.05$ in the analysis. $^{40}$

\section{Demographic Parameters}

The growth rate of the population, $g_{t}$, is set so as to match the growth rate of the Chilean population. From the World Bank's World Development Indicators, I can calculate the growth rate of the population from 1981 to 2016 . For the years after 2016, I predict the values using a linear trend from the years prior. This population growth rate ranges from a high of $1.7 \%$ in the late 1980 s to a low of $0.9 \%$ in 2016 . This I assume that the decline in the population growth rate continues.

\subsubsection{Internally Calibrated}

In the final stage of the estimation, three parameters are internally calibrated to match macroeconomic aggregates in 1980. The discount factor, $\beta$, the weight of consumption in utility, $\gamma$, and the

\footnotetext{
${ }^{39}$ Auerbach et. al. (1999), for example, uses a value of $\sigma=4$ while Dotsey, Li, and Yang (2015) sets $\sigma=1.5$.

${ }^{40}$ More discussion of the choice for the depreciation rate is in the construction of the capital stock series.
} 
productivity term by type, $\varepsilon$, are set so as to match the capital-output ratio of the economy, the aggregate hours worked, and the fraction of total labor income received by each of the types.

The aggregate data used to calculate the target moments come from three sources. First of these sources is historical Chilean National Accounts. The capital-to-output ratio is calculated from this source. National account data provides time series for investment and GDP that are used in this calculation. A time series for the capital stock is constructed using this data. ${ }^{41}$ The calculation returns a ratio of capital-to-output of 1.678 for 1980 .

The second data source, OECD aggregates, is used for the measure of annual hours worked per worker. Data shows that annual hours worked per worker in Chile was 2,572 hours in 1980. I assume discretionary time per week is 100 hours. Therefore, the fraction of time spent working is 0.495 .

Finally, productivity terms in the model are chosen in order to match the fraction of labor income received by each of the types in the model. As described above, these types are meant to represent manual laborers, employees, and managers. The employment survey Encuesta de Ocupación y Desocupación en El Gran Santiago (EOD) is used to calculate the percentage of labor income received by each type. ${ }^{42}$ Manual laborers make up 49 percent of the population and receive 21 percent of labor income, Employees represent 44 percent of the population and receive 52 percent of labor income, managers are 7 percent of the population and receive 27 percent of labor income. The model reproduces these fractions when $\varepsilon=\left\{\varepsilon_{1}, \varepsilon_{2}, \varepsilon_{3}\right\}=\{0.5,1.0,2.3\}$.

\subsection{Model Fit}

This section describes how the model fits the aggregate and micro data along various dimensions. The fit of the model to the aggregate moments is shown in Table 4. The model can reproduce the targeted moment well. In addition to the targeted moments, I include the capital-to-output

\footnotetext{
${ }^{41}$ Details on the construction of the capital stock series is discussed in the technical appendix.

${ }^{42}$ EOD is an employment survey for the Greater Santiago area. Demographic information from the 1982 Chilean census indicate the Santiago is representative of the national population. Therefore, the results from study of EOD are used as representative of the country. More information is contained in the technical appendix.
} 
ratio and annual hours worked per worker from the year 2004 to assess how the model matches the evolution of these variables over time. The model does a good job of fitting these aggregate moments, although only the value for 1980 is used in the calibration. ${ }^{43}$

In addition to these aggregate moments, I also look at the performance of the model in reference to the formality decision as well as the savings decision. First, Table 4 also shows the comparison of average hours worked formally per household to average hours worked informally per household. I show that the model produces a ratio of 4.5. This indicated that roughly 20 percent of hours worked are informal. This ratio in the data in 4.9. The fact that this ratio is nearly the same in the data and the model is somewhat by construction, as this micro-data was used in the estimation of the parameters of the CES function governing this decision. However, this ratio is an aggregate moment while the cross-section is used in estimation. This result indicates that the model can reproduce the size of the informal sector in Chile.

When studying how the predictions of the model match the data on the savings of households, I compare the impact across productivity types and across age. First, consider the differential impact of the savings on two different groups of productivity types: manual laborers combined with employees, and managers. ${ }^{44}$ I look at the ratio of the savings of the managers to the savings of the manual laborers and employees; this is shown in Table 4. This ratio is 3.2 in the data and 4.3 in the model. Therefore, while the model predicts slightly more dispersion in the savings across productivity types than in the data, the model does a fairly good job of matching the data. This shows that while savings of all types increase due to the reform, this increase is larger for those with higher productivity; this is also true in the data.

Second, I look at the age-profile of savings in both the model and the data. This comparison is shown in Figure 1. The figure demonstrates that the model can reproduce the hump-shaped age profile of savings and the level of these savings relative to mean savings in the economy. One short-coming is that the model underpredicts the savings of young households. This result is most

\footnotetext{
${ }^{43}$ Time series for these variables are included in the technical appendix.

${ }^{44}$ These two groups are chosen rather than the three used in the baseline model due to data limitations. The postreform data does not separate the manual laborers and the employees.
} 
likely the result of the assumption that households enter the labor force at age 25 with no assets. The data, however, indicates that young households often have some savings. Despite this, the model does a good job of replicating this key feature of the micro-data. ${ }^{45}$

These tests indicate that the model can reproduce features present in both aggregate and microdata. In the next section, I turn to discuss the policy experiment associated with the 1981 reform.

\section{Transitional Results}

In order to assess the impact of the 1981 Chilean reform, I perform an experiment in which I compare the transition path of the economy under two scenarios. First, I consider an economy in which the pre-1981 pay-as-you-go Social Security system continues unchanged. In order to consider this case, I make an assumption that the government would have been able to continue to pay the pensions of retirees at the same rates without changing the payroll tax. However, I do not assume that the PAYG system is sustainable. In particular, I allow other elements of the government budget constraint to adjust in order to compensate for an underfunded pension program. Additionally, I also assume that the fiscal series are the same in both simulations. ${ }^{46}$ It is assumed that a per-capita lump sum transfer is adjusted in order to balance the government budget. Because historic data is used to form the other variables in the government budget constraint, this term represents the sum of two different items. One is the implicit transfer that is caused because I use marginal labor tax rates rather than average rates. ${ }^{47}$ The other is measurement error or missing categories of data in the government budget constraint. Second, I compare the results of continuing the PAYG system with the results of the change to the mandatory savings program that occurred in Chile.

The transition path and the welfare impact of the policy change is reported. In both cases, the initial state is given by the steady state distributions of household asset holdings and household average annual taxable income as well as the level of government debt in 1980. In the transition

\footnotetext{
${ }^{45}$ Additional discussion of the micro-data and the distributional fit of the model is considered in the technical appendix.

${ }^{46}$ Alternate specifications in which these series are different between the cases are considered in the appendix.

${ }^{47}$ More on this implicit transfer is discussed in McGrattan and Prescott (2017).
} 
paths, historical data is used as inputs for the years 1981 to 2010. These inputs are: government debt; tax rates on consumption, labor income, and corporations; defense spending; and the population growth rate. I assume $t=0$ is the year 1981, the year in which the Chilean reform occurred. I calculate the welfare impact on households of all ages and productivity levels that are in the labor force or retired at the time at the reform and for all new generations that enter the workforce after the reform. I assume that the policy change is unexpected, and that households operate under perfect foresight.

\subsection{Continue PAYG}

First, I simulate the demographic transition path for an economy in which the PAYG Social Security system continued.

Table 5 shows the evolution of aggregates throughout the transition. Under this transition path, output decreases nearly 25 percent with a similar drop in capital stock. Total hours drop nearly 20 percent. This drop is almost entirely caused by decreases in market hours (formal and informal hours) as hours spent in home production remain nearly constant. Consumption increases by around 7 percent-market consumption increases by 10 percent while home production increases by 5 percent. The increase in home consumption is caused by increases in durable spending as hours spent working at home do not change. Investment decreases by 30 percent.

Throughout the demographic transition simulated here, the percentage of GNP spent on financing pensions-which are entirely PAYG pensions in this scenario-increases from 5.9 percent to 19.1 percent. This increase is caused by the aging population and the decrease in output. Aging populations cause the costs of pensions to increase. Therefore, the government must spend more to pay for the PAYG pensions. While the costs are increasing, this number is also larger due to the falling output. As GNP has decreased, this causes the percentage of GNP spent on pensions to increase. The rising costs of pensions puts pressure on the government budget constraint and causes the per-capita transfer used to balance the budget to decrease. Throughout the transition, this per-capita transfer decreases to less than half the level it was prior to the reform. 


\subsection{Reform Occurs}

In order to set up the welfare comparison, I also simulate the economy with the reform. Table 6 shows how the aggregates evolve in this simulation. Output decreases, but by only around 5 percent. Capital stock increases by 11 percent. Therefore, the decrease in output is driven by a drop in market hours worked. The drop in market hours worked is caused by a 20 percent drop in formal hours; informal hours increase by over 60 percent. This large increase is due to the fact that formal hours were low prior to reform. Although they increase drastically, informal hours still represent around 20 percent of total market hours. Therefore, the large drop in formal hours overwhelms the increase in informal hours and causes a decrease in market hours.

The movements in hours worked through the transition represent changing incentives from the reform. First, the decrease in home production hours is caused by movements in the wage. As the wage increases throughout the transition, households substitute away from home production and towards market work. However, the results show a decrease in formal sector work and an increase in informal sector work. This is caused by changes in the incentives for formality versus informality. The reform causes changes in the taxes and well as the retirement pension that is a function of formal sector income. As higher wages push workers towards the market, they now do not have the work formally to be eligible for a pension. Therefore, the workers substitute towards informality, where they can receive the same wage without facing general labor income taxation.

Total consumption increases by 10 percent in the long-run after the reform. This increase is made up of a 21 percent increase in market consumption and a 2 percent increase in home production. Additionally, investment decreases slightly-around 1 percent.

The transition is associated with an increase in up-front costs as the government must finance the pensions of current retirees with lower labor tax revenue as well as a decrease in future costs as the government gets out from under the burden of the PAYG pensions. This is seen in the pension costs and per-capita transfers throughout the transition. Pension payments increase from 5.9 percent to 7.2 percent and 8.2 percent of GNP in the years of the transition. However, they decrease to 1.5 percent of GNP in the long-run as the government is only providing the minimum 
pension guarantee. Therefore, transfers drop immediately but the government can provide higher transfers in the future due to low pension costs. ${ }^{48}$

\subsubsection{Long-Run Welfare Impact}

Figure 2 shows the welfare gains from the reform. The welfare gains are measured as a percentage of remaining lifetime market consumption for cohorts working or retired at the time of the reform. Welfare change is measured as a percentage of lifetime market consumption for cohorts that entered the labor force after the reform. It is important to note that the gains are measured as a percentage of market consumption rather than total consumption. This will be important when I analyze the impact of informality and home production as the market good is the only good present in all the cases I consider.

This figure shows large long-run gains from the reform. These gains are nearly 10 percent of lifetime consumption for the manual laborers; the gains are 15 percent of lifetime consumption for employees and managers. These long run gains are driven by two factors. First, the reform removes the distortion caused by the PAYG payroll tax. Second, the reform is associated with a capital deepening as the Social Security system no longer crowds out private savings. In order to isolate the impact of the removal of distortions, I simulate the model as a small open economy rather than a closed economy. Table 7 shows the results. When I consider a small open economy, long-run welfare gains decrease by between 3 and 6 percent points. For manual laborers the gains decrease from 7 percent to 4 percent. For employee and managers gains decrease from 16 percent to 10 percent and 13 percent for the two groups, respectively. Therefore, most of the gains are the result of the removal of the distortionary tax associated with the PAYG system, but capital deepening also plays an important role.

\footnotetext{
${ }^{48}$ Even in the long-run steady state, transfers are below their pre-steady state levels. However, these transfers are higher than those in the long-run steady state in which PAYG continues. The low long-run transfers are a result of the other fiscal series which are exogenously fed into the model.
} 


\subsubsection{Transitional Welfare Impact}

Generations that live through the transition between the systems, particularly those who are retired or nearing retirement at the time of reform experience welfare losses. Two groups experience the largest welfare losses: those generations of manual laborers who are oldest at the time of reform and employees and managers who are within 5 years of retirement at the time of reform.

\section{Manual Laborers}

Retired manual laborers experience large losses throughout the transition due to the assumption of fiscal series being constant in both simulations as well as due to falling transfers.

Consider an experiment in which I assume that all changes that occur in the fiscal variables after 1980 were chosen in order to help the reform. Therefore, all fiscal series are held constant in the case in which PAYG continues but they evolve according to data in the case of the reform. The transitional welfare results of this experiment are shown in Figure 3. ${ }^{49}$ When I consider this case, a large portion of the welfare losses for these oldest generation of manual laborers disappears. If the government builds up debt in the case of continuing PAYG, it is able to keep transfers higher through the first years of the demographic transition path I simulate. Therefore, the welfare losses for these generations shrinks in this experiment.

However, even in this counterfactual, these oldest manual laborers still experience welfare losses of roughly 3 percent. These remaining losses are driven by the lower transfers received. Transfers must fall in order to continue to pay the pensions in the presence of falling labor tax revenue from new workers. Manual laborers are most affected by this because these transfers, due to their lump-sum structure, are a larger fraction of their income.

\section{Employees and Managers}

Higher productivity workers who are nearing retirement at the time of the reform experience large losses due to the structure of the transitional policy. In particular, these groups are hurt by the way

\footnotetext{
${ }^{49}$ Additional discussion of this experiment and variations on it are included in the technical appendix.
} 
in which the value of the recognition bond received to represent prior contribution to PAYG was calculated. Recall the formula for the per-period payout from the recognition bond:

$$
\frac{1}{J-R}\left[0.8 \bar{y}_{t}\left(\frac{t^{*}-t_{0}}{35}\right) v_{G} v_{A}(1.04)^{R-t^{*}}\right]
$$

where $t^{*}$ represented the year of the reform (1981) and $t_{0}$ was the year a particular household entered the workforce. Important for comparison is that this formula allows the payout to be written as a percentage of the average taxable earnings, $\bar{y}_{t}$, just as the PAYG pension was.

$$
\frac{1}{J-R}\left[0.8\left(\frac{t^{*}-t_{0}}{35}\right) v_{G} v_{A}(1.04)^{R-t^{*}}\right] \bar{y}_{t}=I R R * \bar{y}_{t}
$$

where I will refer to $I R R$ as the implied replacement rate for the recognition bond policy. A few features of this implied replacement rate are: it is dependent on the cohort of the individual, independent of general equilibrium effects on the interest rate as the bond paid a fixed real interest rate of 4 percent, and nearly independent of wage effects as the cohorts discussed here are close to retirement at the time of the reform. Figure 4 shows this implied replacement rate for cohorts where dashed lines at 0.7 and 1.00 represent the replacement rate that blue-collar and white-collar workers would have received under PAYG, respectively. The dotted line shows the average payed out in the PAYG system. It is obvious from this graph that for all cohorts of employees and managers who live through the transition the recognition bond pays less than they would have received under PAYG. Those cohorts closest to retirement do not have time to accumulate additional savings to buffer against this falling income. Therefore, these cohorts experience large welfare losses.

Overall, these results are caused by different effects depending on the cohort in question. For the future cohorts, welfare gains are driven by a combination of the removal of the distortionary tax and the capital deepening caused by increased savings. For transitional generations, the welfare losses are caused by the transitional details of the reform. The oldest generations of manual laborers are hurt due to falling tax revenue and thus falling transfers. Employees and managers close to retirement are hurt due to the transitional policy paying less than they would have received 
under PAYG.

\section{Impact of Informality and Home Production}

\subsection{Calibration}

In order to study cases without the options of informality and home production, I must update the calibration of the model to match the aggregate data. In particular, I must update the calibration to match the capital-to-output ratio of the economy and the aggregate hours worked per worker in the economy. Without the options of home production and informality, the calibration will result in different parameter values. Table 8 shows the parameter values for these calibrations; Table 9 shows the fit of these calibrations.

The key difference between these calibrations is the result of the weight of consumption in utility, $\gamma$. The value for this parameter varies significantly across the cases considered. These values must be different in order to match the aggregate market hours, formal and informal hours, worked in the economy. Consider, first, the economy without either home production or informality. In order to match the fraction of time spent working, this parameter must increase moderately to 0.587. The impact of home production and informality independently, however, are much different. Specifically, excluding only informality (and including home production) requires an increase in this parameter while excluding only home production (and including informality) requires $\gamma$ to decrease. In order to match the fraction of time spent working of 0.495 , this value must be 0.876 in an economy where the only outside option is home production and 0.297 in an economy with only informality.

\subsection{Results}

The long-run welfare results are shown in Table 10. These results show that including informality and home production leads to larger long-run welfare gains that in an economy without these 
options. However, these two outside options to formal work have different impacts. In particular, the option of home production increases long run gains while the option of informality does not largely impact long-run gains.

The differing impact of these two labor options can be understood with a combination of elasticity in the case of both home production and government revenue and price effects which are specific to informality. Changes in elasticity impact the distortionary nature of the PAYG payroll tax. Government revenue effects work through the impact on tax revenue and transfers as workers move to informality; Price effects are the result of wage changes that occur throughout the transition path between the programs.

Consider, first, the impact of including home production. The presence of home production implies a higher labor supply elasticity than in the alternative economies. Because of this higher labor elasticity, the payroll tax from the pay-as-you-go Social Security system is more distortionary. By having the outside option to the formal sector, agents increase home work to avoid this distortion. Therefore, a reform that decreases the payroll tax leads to higher welfare gains in economies that have a home production sector.

The quantitative impact of including home production is shown as the difference between column four and column two of Table 10. This is the same result that has been shown in Dotsey, Li, and Yang (2015). Specifically, including home production in the model increases aggregate longrun welfare gains from roughly 4 percent to nearly 11 percent. This increase is seen in welfare increases for each of the three types considered: welfare gains for manual laborers increase from around 2 percent to nearly 6 percent and welfare gains for both employees and managers increase from around 6 percent to roughly 16 percent.

Now, consider the impact of informality. In contrast to home production, informality creates two different effects. The first is government revenue effect. The second is related to the increase in the wage caused by the transition.

\section{The option of informality decreases government revenue and, therefore, transfers}

The inclusion of informality gives an outside option to formality while the household can 
still receive a wage to fund market consumption. Throughout the transition to the privatized system, the benefits of formality are decreased as workers no longer have to work formally to receive retirement income. Therefore, throughout the transition, I observe a increase in informal hours and a decrease in formal hours. This movement, combined with the elimination of the contribution rate from the PAYG system, decreases government revenue.

Therefore, the presence of informality is also associated with lower transfers. These lower transfers cause lower welfare gains in economies with informality.

\section{Informality allows workers to take advantage of higher wages without facing remaining} distortionary taxes

In contrast to the impact via the government budget constraint, the inclusion of informality increases welfare gains due to wage effects. The pay-as-you-go Social Security system crowds out savings and keeps interest rates high. The reform, which increases private savings, is accompanied by a fall in the interest rate and an increase in the wage. Additionally, while the reform removes the distortion caused by the Social Security contribution rate, the distortion of general income taxation remains constant across both scenarios. The presence of the informal sector allows households to achieve the higher wage without this distortion. Therefore, the presence of informality leads to higher long-run welfare gains due to high wages without distortions.

The quantitative impact of including only informality (shown as the difference between the fourth column and the third column of Table 10) indicates that these two mechanisms are similar in magnitude. Specifically, including informality keeps aggregate welfare gains at roughly 4 percent.

The difference between the first column, which shows the baseline impact, and the fourth column of Table 10 demonstrates the impact of having both options. The welfare impact of reform in an economy featuring both these mechanisms leads to roughly the same gains as including only home production. This supports the finding that the welfare impacting forces of informality cancel one another out. 


\section{Conclusion}

In conclusion, this work supports the literature on Social Security privatization by showing large long-run welfare gains from the reform. However, as with the literature, these long-run gains are financed by losses for those generations that live through the transition between the programs. These gains and losses are different depending on the type of employment the worker had before the reform. Specifically, long-run gains are roughly 15 percent for employees and managers while they are nearly 10 percent for manual laborers. In the transition two groups experience losses of 15 percent. Manual laborers who are already retired at the time of reform experience losses as the government must continue to pay PAYG pensions to current retirees while receiving less tax revenue due to the removal of the Social Security payroll tax. White-collar workers within five years of retirement experience large losses as the transitional policy used in the Chilean reform pays out less than these workers would have received from the PAYG program.

My model also allows me to analyze how home production and informality impact these welfare gains. Both home production and informality increase long-run welfare gains. The option to work at home increases the elasticity of labor supply and causes the payroll tax to be more distortionary. Therefore, there are larger welfare gains from removing the payroll tax as part of the reform. In addition to this, informality has two effect which work against each other. First, informality decreases government revenue as workers move into the informal sector. This lower revenue is associated with lower transfers and lower long-run welfare gains. Second, informality allows workers to take advantage of wage growth that occurs throughout the transition without facing remaining taxation. This wage effect causes higher welfare gains in an economy in which informality is an option. Quantitatively, including informality does not largely change long-run welfare gains. 


\section{References}

[1] Acua, Rodrigo and Augusto Iglesias. 2001 Chile's Pension Reform after 20 Years. Washington D.C.: The World Bank, Discussion Paper 0129, December.

[2] Aguiar, Mark, Eric Hurst, and Loukas Kararbarbounis, Time Use during the Great Recession. American Economic Review, 2013, 103(5). 1664-1696.

[3] Arenas de Mesa, Alberto, Jere Behrman, David Bravo, Olivia Mitchell and Petra Todd (2007), The Chilean Pension Reform Turns 25: Lessons form the Social Protection Survey, ed. Stephen Kay and Tapen Sinha, in Lessons from Pension Reform in the Americas, Oxford University Press, 2007. Pages 23-58.

[4] Arenas de Mesa, Alberto and Veronica Montecinos. 1999. The Privatization of Social Security and Women's Welfare: Gender Effects of the Chilean Reform. Latin American Research Review.

[5] Attanasio, Orazio P., Costas Meghir, and Andres Otero. 2011. Formal Labor Market and Pension Wealth: Evaluating the 2008 Chilean Pension Reform. Institute for Fiscal Studies. Working paper.

[6] Benhabib, Jess, Richard Rogerson, and Randall Wright. 1991. Homework in Macroeconomics: Household Production and Aggregate Fluctuations. Journal of Political Economy 99(6): 1166-1187.

[7] Behrman, Jere R., Maria Cecilia Calderon, Olivia Mitchell, Javiera Vasquez, David Bravo. 2011. First-Round Impacts of the 2008 Chilean Pension System Reform. PARC Working Paper Series. 33.

[8] Centro Micro Datos, Facultad Economía Negocias, Universidad de Chile, Encuesta de Ocupación y Desocupación en el Gran Santiago. 
[9] Chang, Yongsung and Frank Schorfheide, Labor-Supply Shifts amd Economic Fluctuations, Journal of Monetary Economics, November 2003, 50 (8), 1751-1768.

[10] Conesa, Juan C., and Dirk Krueger. 1999. Social Security Reform with Heterogeneous Agents. Review of Economic Dynamics 2(4): 757-795.

[11] Dotsey, Michael, Wenli Li, and Fang Yang. 2015. Home Production and Social Security Reform. European Economic Review, 73: 151-150.

[12] Edwards, Sebastian. The Chilean Pension Reform: A Pioneering Program in Privatizing Social Security, Martin Feldstein, ed., 33-57 (Chicago: University of Chicago Press, 1998)

[13] Fang, Lei and Guozhong Zhu. 2012, Home Production Technology and Time AllocationEmpirics, Estimation, and Implications. FRB Atlanta Working Paper No. 2012-19.

[14] Feldstein, Martin, ed. 1998. Privatizing Social Security (Chicago: University of Chicago Press).

[5] Huang, He, Selahattin Imrohoroglu, and Thomas Sargent. 1997. Two Computations to Fund Social Security. Macroeconomic Dynamics. (1) 1997. 7-44.

[15] Huggett, Mark, and Juan Carlos Parra. 2010. How Well Does the U.S. Social Insurance System Provide Social Insurance? Journal of Political Economy 118(1): 76-112

[16] Imrohoroglu, Selahattin, and Sagiri Kitao. 2012. Social Security Reforms: Benefit Claiming, Labor Force Participation, and Long-Run Sustainability. American Economic Journal: Macroeconomics 4(3): 96-127.

[17] Instituto Nacional de Estadísticas, Encuesta ENUT

[18] International Labour Office (Geneva). 2018. Women and Men in the Informal Economy: A Statistical Picture. Third Edition. (Geneva). 
[19] James, Estelle, and Augusto Iglesias. 2007. Disability Insurance with Prefundgin and Private Participation: The Chilean Model. Michigan Retirement Research Center, Policy Brief Number 4. Ann Arbor, MI: University of Michigan.

[20] Jofré, José, Rolf Lüders, Gert Wagner. 2000. Economía Chilena 1810-1995. Cuentas Fiscales. Ponífica Universidad Católica de Chile: Working Paper Number 188

[21] Joubert, Clement. 2010. Dynamic Labor Supply and Savings Incentive Under a Privatized Pension System: Evidence from Chile. Publicly Accesible Penn Dissertations. 112.

[22] Joubert, Clement. 2015. Pension Design with a Large Informal Labor Market: Evidence from Chile. International Economic Review, 56: 673-694.

[23] Joubert, Clement and Petra Todd. 2011. How the Design of a Pension System Influences Old Age Poverty and Gender Equity: A Study of Chile's Private Retirement Accounts System. Working Paper, University of Pennsylvania.

[24] Kotlikoff, L.J., K. Smetters, and J. Walliser (1999). Privatizing Social Security in the United States - Comparing the Options. Review of Economic Dynamics 2(3), 532-574.

[25] Kritzer, Barbara E. 2008. Chile's Next Generation Pension Reform. Social Security Bulletin 68(2). U.S. Social Security Administration.

[26] Kritzer, Barabra E. 2005. Individual Accounts in Other Countries. Social Security Bulletin 66(1). U.S. Social Security Administration.

[27] Kritzer, Barbara E., Stephen J. Kay, and Tapen Sinha. 2011. Next Generation of Individual Account Pension Reforms in Latin American. Social Security Bulletin 71(1). U.S. Social Security Administration.

[28] Ministerio Trabajo y Previsión Social, Encuesta EPS

[29] McGrattan, Ellen R., and Edward C. Prescott. 2017. On Financing Retirement with and Aging Population. Quantitative Economics, 8: 75-115. 
[30] McGrattan, Ellen, Richard Rogerson, and Randall Wright. 1997. An Equilibrium Model of the Business Cycle with Household Production and Fiscal Policy. International Economic Review, 38(2): 267-290.

[31] Nishiyama, Shinichi, and Kent Smetters. 2007. Does Social Security Privatization Produce Efficiency Gains? Quarterly Journal of Economics 122(4): 1677-1719.

[32] Rupert, Peter, Richard Rogerson, and Randall Wright, "Estimating Substitution Elasticities in Household Production Models," Economic Theory, June 1995, 6(1), 179-93. 
Table 1: Contribution Rates by Type of Employment

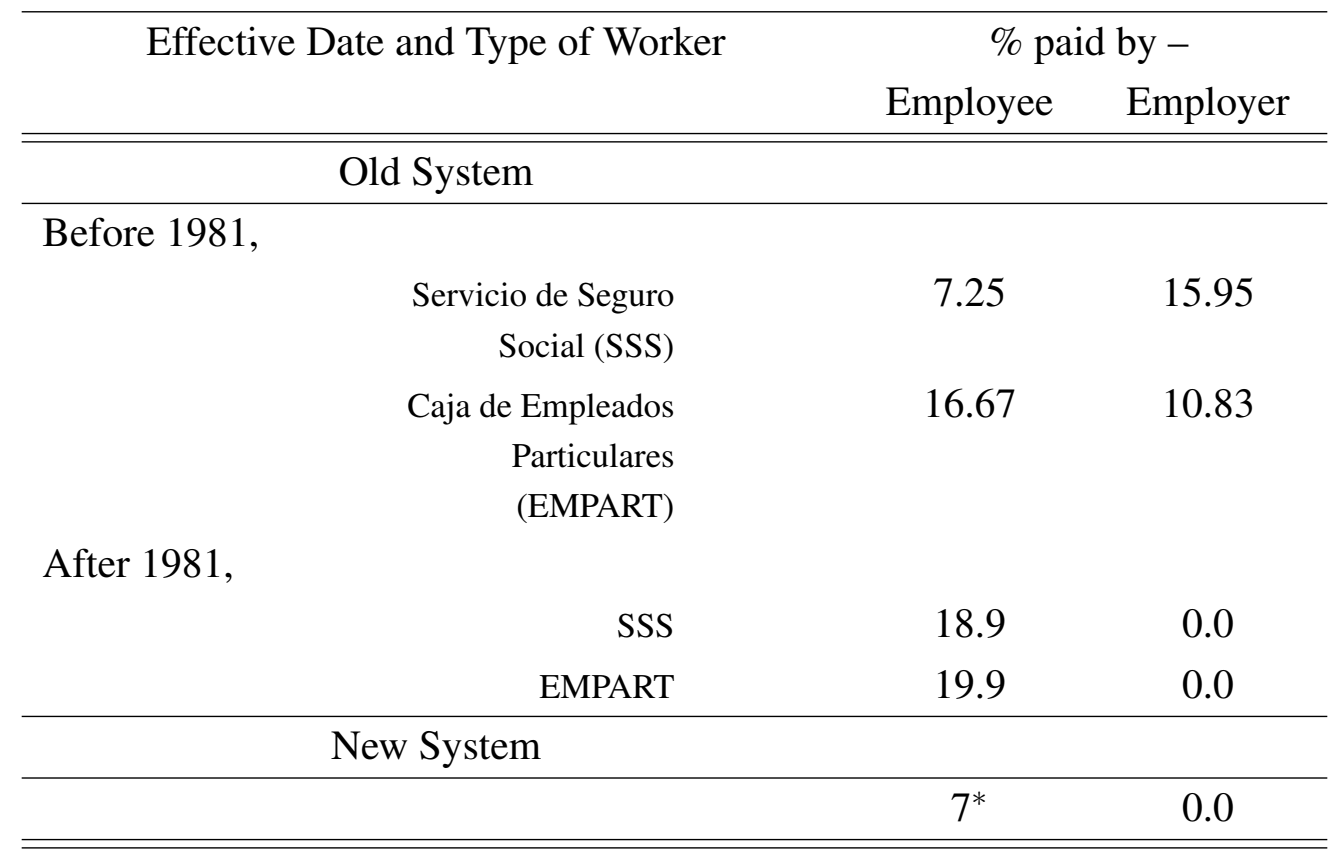

* Note: the $7 \%$ contribution rate under the new system is calculated based on the contribution for health insurance and disability insurance.

Table 2: Estimated Parameter Values

\begin{tabular}{ccccc}
\hline Function & \multicolumn{2}{c}{$\begin{array}{c}\text { Estimate } \\
(\mathrm{SE})\end{array}$} & $\begin{array}{c}\text { Elasticity of } \\
\text { Substitution* }\end{array}$ \\
\hline$\left\{a_{1} c_{m}^{b_{1}}+\left(1-a_{1}\right) c_{h}^{b_{1}}\right\}^{1 / b_{1}}$ & $a_{1}=\begin{array}{c}0.309 \\
(0.052)\end{array}$ & $b_{1}=\begin{array}{c}0.144 \\
(0.046)\end{array}$ & $\eta_{1}=1.168$ \\
$\left\{a_{2} h_{f}^{b_{2}}+\left(1-a_{2}\right) h_{i}^{b_{2}}\right\}^{1 / b_{2}}$ & $a_{2}=\begin{array}{c}0.441 \\
(0.051)\end{array}$ & $b_{2}=\begin{array}{c}0.847 \\
(0.056)\end{array}$ & $\eta_{2}=6.536$ \\
$\left\{a_{3} d^{b_{3}}+\left(1-a_{3}\right) h_{h}^{b_{3}}\right\}^{1 / b_{3}}$ & $a_{3}=\begin{array}{c}0.555 \\
(0.118)\end{array}$ & $b_{3}=\begin{array}{c}0.271 \\
(0.272)\end{array}$ & $\eta_{3}=1.372$ \\
\hline
\end{tabular}

*The elasticity of substitution shown is that which is implied by the estimation of the $b$ parameters using the equation $\eta_{i}=\frac{1}{1-b_{i}}, i=1,2,3$ 
Table 3: Other Parameters

\begin{tabular}{|c|c|c|c|c|}
\hline Parameter & Description & Value & Target & Source \\
\hline$\beta$ & Discount rate & 0.901 & $\frac{K}{Y}=1.678$ & $\begin{array}{l}\text { National } \\
\text { Accounts }\end{array}$ \\
\hline$\gamma$ & $\begin{array}{l}\text { Weight of } \\
\text { consumption } \\
\text { in utility }\end{array}$ & 0.435 & $\begin{array}{l}\text { Annual hours worked } \\
\text { per worker }=2572\end{array}$ & OECD \\
\hline$\varepsilon$ & Productivity & $\{0.5,1,2.3\}$ & $\begin{array}{c}\text { Manuel laborers: } 21 \% \\
\text { Employees: } 52 \% \\
\text { Managers: } 27 \%\end{array}$ & EOD 1980 \\
\hline$\alpha$ & $\begin{array}{l}\text { Weight of } \\
\text { capital in } \\
\text { production }\end{array}$ & 0.33 & & \\
\hline$\delta$ & Depreciation & 0.05 & & \\
\hline$\sigma$ & Risk aversion & 2 & & \\
\hline$J$ & $\begin{array}{c}\text { Retirement } \\
\text { Age }\end{array}$ & 40 & Retirement age of 65 & \\
\hline$T$ & $\begin{array}{c}\text { End of Life } \\
\text { Age }\end{array}$ & 55 & $\begin{array}{l}\text { Exit the model at age } \\
\qquad 80\end{array}$ & \\
\hline
\end{tabular}


Table 4: Model Fit

Baseline

\begin{tabular}{lcc}
\hline Targeted Moments & Data & Model \\
\hline \hline Capital output ratio & 1.678 & 1.681 \\
Aggregate hours worked & 0.495 & 0.497 \\
Fraction of GNP spent on social & 0.144 & 0.144 \\
programs & & \\
Fraction of labor income earned by & 0.210 & 0.251 \\
manual laborers & & 0.521 \\
Fraction of labor income earned by & 0.520 & \\
employees & & 0.228 \\
Fraction of labor income earned by & 0.270 & \\
managers & & 4.3 \\
\hline $\begin{array}{l}\text { Untargeted Moments } \\
\text { Capital output ratio (2004) }\end{array}$ & & \\
\hline \hline $\begin{array}{l}\text { Aggregate hours worked (2004) } \\
\text { formal hours per HH }\end{array}$ & & \\
\hline savings of manual laborers and employees & & \\
\hline
\end{tabular}


Figure 1: Savings by Age: Model and Data

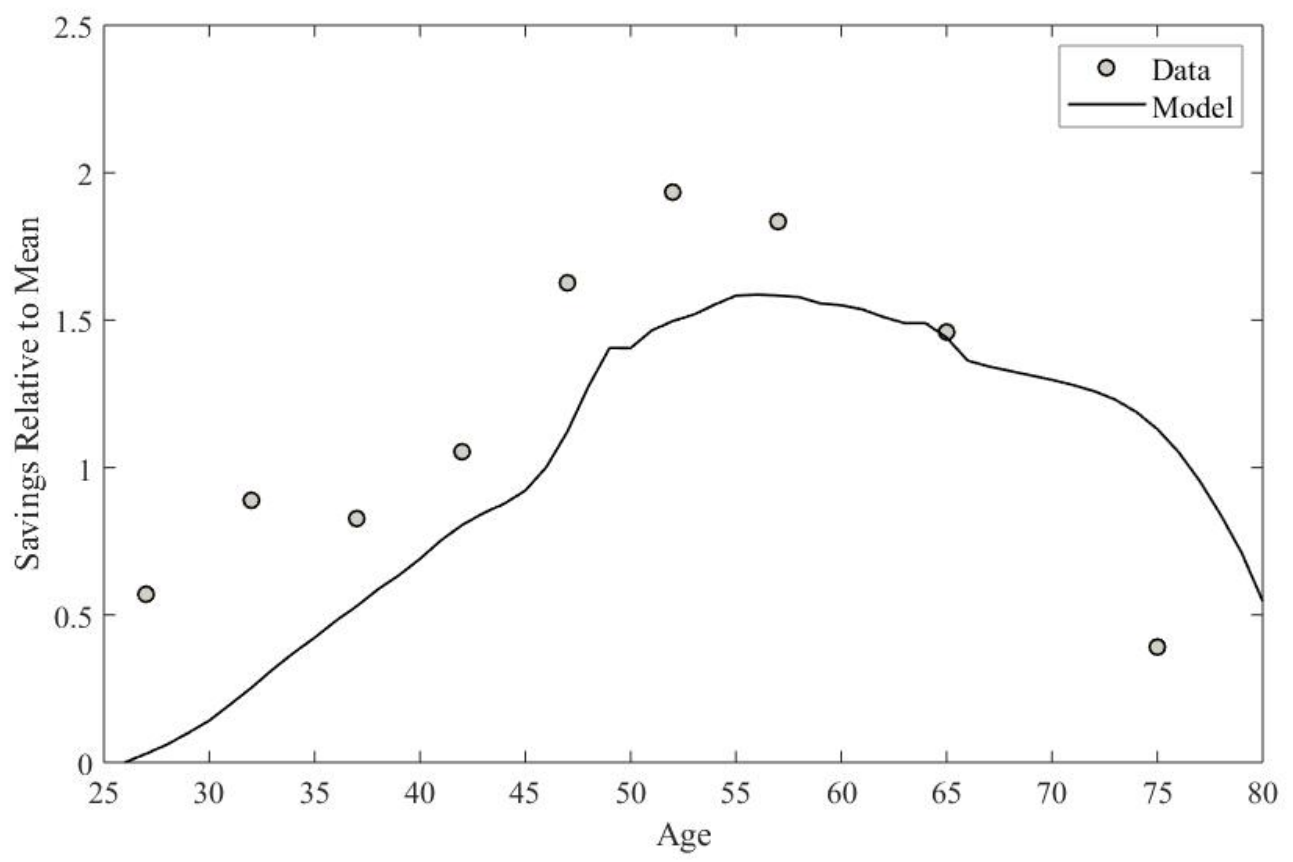

Figure 2: Welfare Impact by Cohort

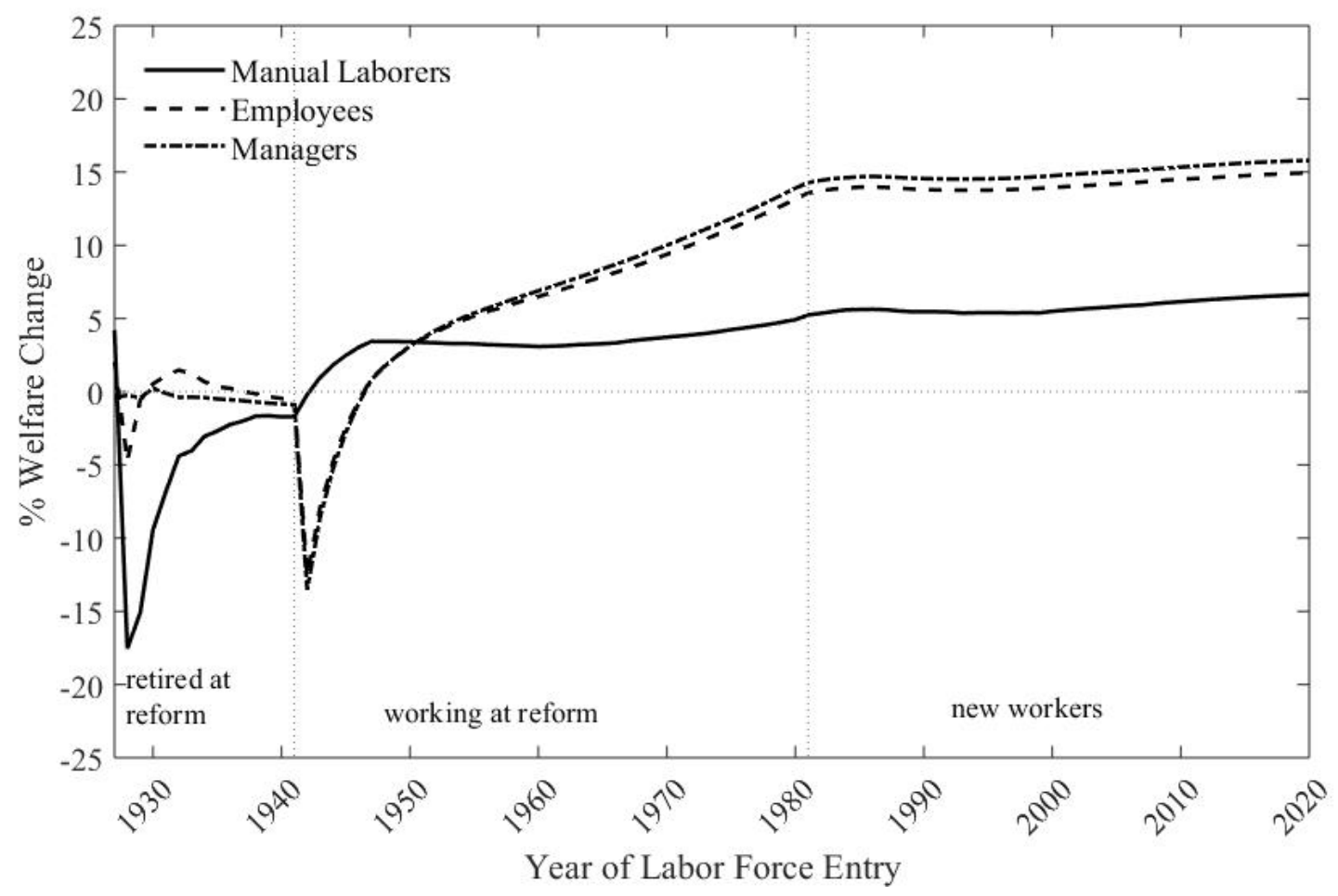


Table 5: Aggregates, Prices, and Government Budget through the Transition

Continue PAYG Program

\begin{tabular}{|c|c|c|c|c|c|c|c|}
\hline & & 1980 & $\begin{array}{l}1981- \\
2000\end{array}$ & $\begin{array}{l}2001- \\
2020\end{array}$ & $\begin{array}{l}2021- \\
2050\end{array}$ & $\begin{array}{l}2051- \\
2080\end{array}$ & $\begin{array}{l}\text { Steady } \\
\text { State* }\end{array}$ \\
\hline Output & & 1.000 & 0.846 & 0.848 & 0.800 & 0.778 & 0.758 \\
\hline Capital Stock & & 1.000 & 0.841 & 0.863 & 0.817 & 0.785 & 0.783 \\
\hline Hours & & 1.000 & 0.885 & 0.885 & 0.847 & 0.831 & 0.812 \\
\hline \multirow{7}{*}{ Consumption } & $\begin{array}{l}\text { Formal } \\
\text { Hours }\end{array}$ & 1.000 & 0.850 & 0.855 & 0.804 & 0.781 & 0.753 \\
\hline & $\begin{array}{l}\text { Informal } \\
\text { Hours }\end{array}$ & 1.000 & 0.755 & 0.760 & 0.715 & 0.696 & 0.670 \\
\hline & Home Hours & 1.000 & 1.002 & 0.990 & 0.981 & 0.983 & 0.989 \\
\hline & & 1.000 & 1.008 & 1.036 & 1.057 & 1.062 & 1.067 \\
\hline & $\begin{array}{c}\text { Market } \\
\text { Consumption }\end{array}$ & 1.000 & 1.010 & 1.051 & 1.081 & 1.087 & 1.093 \\
\hline & $\begin{array}{l}\text { Durable } \\
\text { Spending }\end{array}$ & 1.000 & 1.011 & 1.055 & 1.089 & 1.095 & 1.101 \\
\hline & $\begin{array}{c}\text { Home } \\
\text { Consumption }\end{array}$ & 1.000 & 1.007 & 1.025 & 1.038 & 1.043 & 1.048 \\
\hline Investment & & 1.000 & 0.982 & 0.965 & 0.803 & 0.736 & 0.691 \\
\hline Interest Rate & & 1.000 & 0.997 & 0.997 & 0.996 & 0.996 & 0.992 \\
\hline Wage & & 1.000 & 0.993 & 0.989 & 0.991 & 0.992 & 1.004 \\
\hline $\begin{array}{l}\text { Per-capita } \\
\text { Transfer }\end{array}$ & & 1.000 & 0.629 & 0.794 & 0.607 & 0.514 & 0.419 \\
\hline $\begin{array}{c}\text { Consumption } \\
\text { Tax }\end{array}$ & & 0.073 & 0.075 & 0.054 & 0.053 & 0.054 & 0.056 \\
\hline Labor Tax & & 0.224 & 0.227 & 0.226 & 0.226 & 0.226 & 0.226 \\
\hline Corporate Tax & & 0.081 & 0.080 & 0.082 & 0.086 & 0.088 & 0.089 \\
\hline \multirow{4}{*}{$\begin{array}{l}\text { Retirement } \\
\text { Transfer }\end{array}$} & & 0.059 & 0.079 & 0.101 & 0.145 & 0.169 & 0.191 \\
\hline & $\begin{array}{c}\text { PAYG } \\
\text { Pension }\end{array}$ & 0.059 & 0.079 & 0.101 & 0.145 & 0.169 & 0.191 \\
\hline & $\begin{array}{l}\text { Recognition } \\
\text { Bond }\end{array}$ & 0.000 & 0.000 & 0.000 & 0.000 & 0.000 & 0.000 \\
\hline & $M P G$ & 0.000 & 0.000 & 0.000 & 0.000 & 0.000 & 0.000 \\
\hline $\begin{array}{l}\text { Per-capita } \\
\text { transfer }\end{array}$ & & 0.226 & 0.136 & 0.189 & 0.152 & 0.132 & 0.112 \\
\hline Debt & & 0.182 & 0.182 & 0.361 & 0.056 & 0.035 & 0.035 \\
\hline $\begin{array}{l}\text { Government } \\
\text { Spending }\end{array}$ & & 0.021 & 0.021 & 0.041 & 0.024 & 0.019 & 0.019 \\
\hline
\end{tabular}

Note: Values for aggregates and prices are reported relative to the pre-reform steady state.

Values for government revenue and spending variables are reported as a percentage of GNP.

* The steady state value is the average of these values for the last 5 years of the transition

2120-2124 
Table 6: Aggregates, Prices, and Government Budget through the Transition

Transition from PAYG to Current Chilean Policy

\begin{tabular}{|c|c|c|c|c|c|c|c|}
\hline & & 1980 & $\begin{array}{l}1981- \\
2000\end{array}$ & $\begin{array}{l}2001- \\
2020 \\
\end{array}$ & $\begin{array}{l}2021- \\
2050\end{array}$ & $\begin{array}{l}2051- \\
2080 \\
\end{array}$ & $\begin{array}{l}\text { Steady } \\
\text { State* }^{*}\end{array}$ \\
\hline Output & & 1.000 & 0.900 & 0.927 & 0.960 & 0.949 & 0.942 \\
\hline Capital Stock & & 1.000 & 0.896 & 0.985 & 1.063 & 1.057 & 1.111 \\
\hline Hours & & 1.000 & 0.893 & 0.896 & 0.887 & 0.875 & 0.855 \\
\hline \multirow{7}{*}{ Consumption } & $\begin{array}{c}\text { Formal } \\
\text { Hours }\end{array}$ & 1.000 & 0.801 & 0.814 & 0.828 & 0.816 & 0.792 \\
\hline & $\begin{array}{c}\text { Informal } \\
\text { Hours }\end{array}$ & 1.000 & 1.638 & 1.664 & 1.693 & 1.668 & 1.619 \\
\hline & Home Hours & 1.000 & 0.920 & 0.892 & 0.819 & 0.808 & 0.806 \\
\hline & & 1.000 & 1.121 & 1.155 & 1.116 & 1.101 & 1.100 \\
\hline & $\begin{array}{c}\text { Market } \\
\text { Consumption }\end{array}$ & 1.000 & 1.193 & 1.250 & 1.223 & 1.207 & 1.206 \\
\hline & $\begin{array}{l}\text { Durable } \\
\text { Spending }\end{array}$ & 1.000 & 1.219 & 1.283 & 1.261 & 1.244 & 1.243 \\
\hline & $\begin{array}{c}\text { Home } \\
\text { Consumption }\end{array}$ & 1.000 & 1.066 & 1.083 & 1.035 & 1.021 & 1.020 \\
\hline Investment & & 1.000 & 1.137 & 1.186 & 1.097 & 0.988 & 0.991 \\
\hline Interest Rate & & 1.000 & 0.995 & 0.989 & 0.983 & 0.982 & 0.975 \\
\hline Wage & & 1.000 & 1.014 & 1.025 & 1.040 & 1.042 & 1.059 \\
\hline $\begin{array}{l}\text { Per-capita } \\
\text { Transfer }\end{array}$ & & 1.000 & 0.268 & 0.435 & 0.728 & 0.766 & 0.756 \\
\hline $\begin{array}{c}\text { Consumption } \\
\text { Tax }\end{array}$ & & 0.073 & 0.083 & 0.054 & 0.034 & 0.034 & 0.034 \\
\hline Labor Tax & & 0.224 & 0.127 & 0.127 & 0.126 & 0.126 & 0.125 \\
\hline Corporate Tax & & 0.081 & 0.075 & 0.076 & 0.081 & 0.084 & 0.085 \\
\hline \multirow{4}{*}{$\begin{array}{c}\text { Retirement } \\
\text { Transfer }\end{array}$} & & 0.059 & 0.072 & 0.082 & 0.023 & 0.014 & 0.015 \\
\hline & $\begin{array}{c}\text { PAYG } \\
\text { Pension }\end{array}$ & 0.059 & 0.025 & 0.000 & 0.000 & 0.000 & 0.000 \\
\hline & $\begin{array}{c}\text { Recognition } \\
\text { Bond }\end{array}$ & 0.000 & 0.047 & 0.082 & 0.012 & 0.000 & 0.000 \\
\hline & $M P G$ & 0.000 & 0.000 & 0.000 & 0.011 & 0.014 & 0.015 \\
\hline $\begin{array}{l}\text { Per-capita } \\
\text { transfer }\end{array}$ & & 0.226 & 0.056 & 0.109 & 0.176 & 0.187 & 0.186 \\
\hline Debt & & 0.182 & 0.361 & 0.056 & 0.035 & 0.035 & 0.035 \\
\hline $\begin{array}{c}\text { Government } \\
\text { Spending }\end{array}$ & & 0.021 & 0.041 & 0.024 & 0.019 & 0.019 & 0.019 \\
\hline
\end{tabular}

Note: Values for aggregates and prices are reported relative to the pre-reform steady state.

Values for government revenue and spending variables are reported as a percentage of GNP.

* The steady state value is the average of these values for the last 5 years of the transition

2120-2124 
Figure 3: Welfare Impact by Cohort: Series Constant in PAYG

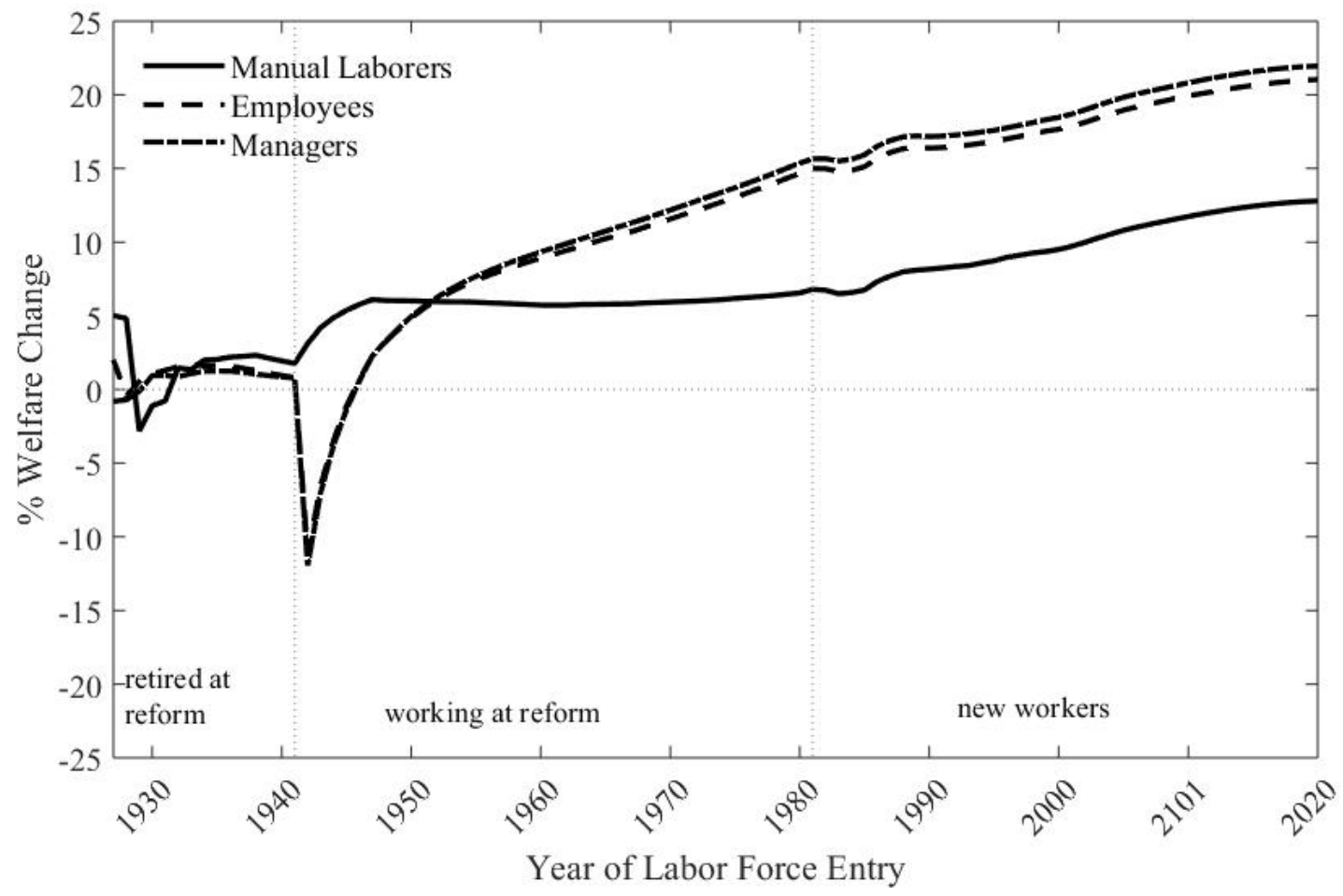

Figure 4: Implied Replacement Rate from the Recognition Bond Policy

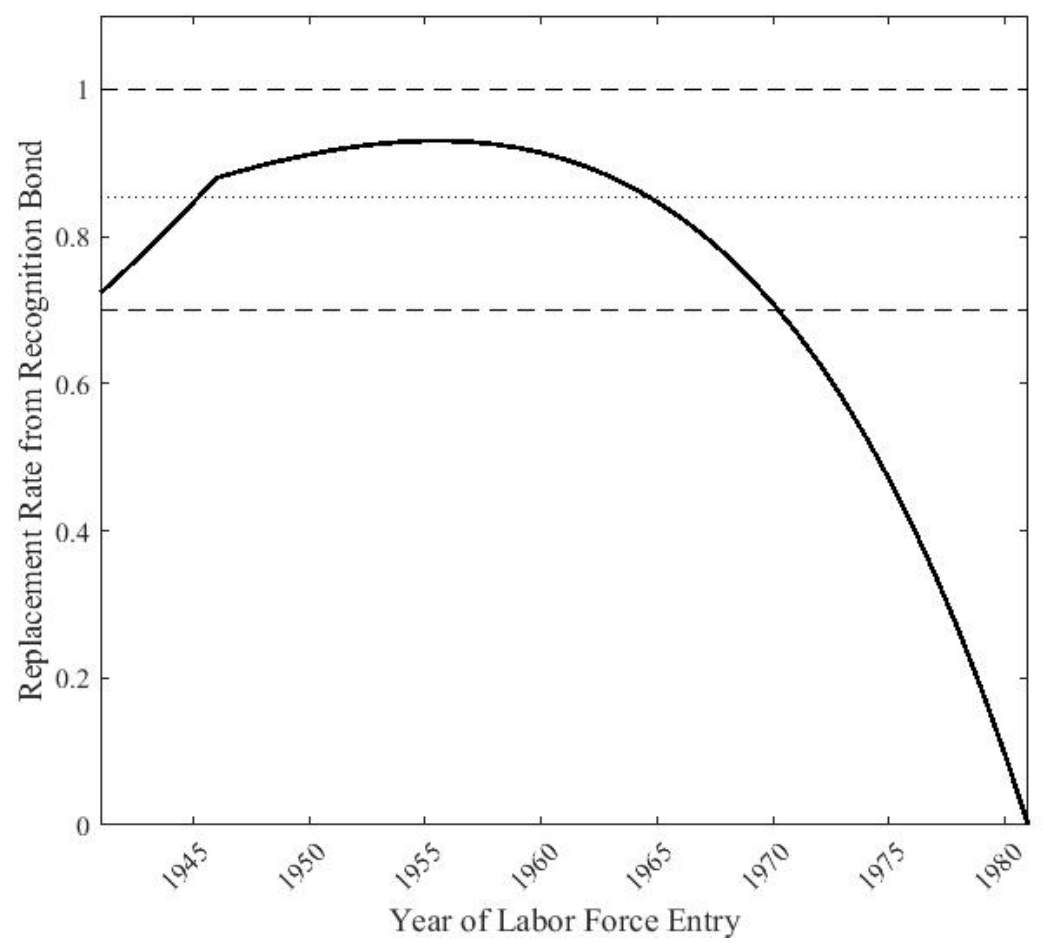


Table 7: Impact of Capital Deepening on Long-Run Welfare Gains

\begin{tabular}{ccc}
\hline & Baseline & $\begin{array}{c}\text { Small Open } \\
\text { Economy }\end{array}$ \\
\hline \hline Total & 11.1 & 6.9 \\
\hline Manual Laborers & 6.8 & 3.6 \\
Employees & 15.2 & 9.6 \\
Managers & 16.2 & 12.9 \\
\hline
\end{tabular}

Table 8: Calibrated Parameters

Informality and Home Production Experiments

\begin{tabular}{ccccc}
\hline Parameter & Baseline & $\begin{array}{c}\text { Formality }+ \\
\text { Home } \\
\text { Production }\end{array}$ & $\begin{array}{c}\text { Formality }+ \\
\text { Informality }\end{array}$ & $\begin{array}{c}\text { Only } \\
\text { Formality }\end{array}$ \\
\hline \hline$\beta$ & 0.901 & 0.907 & 0.900 & 0.915 \\
$\gamma$ & 0.435 & 0.876 & 0.297 & 0.587 \\
$\left\{\varepsilon_{1}, \varepsilon_{2}, \varepsilon_{3}\right\}$ & $\{0.5,1.0,2.3\}$ & $\{0.5,1.0,2.3\}$ & $\{0.5,1.0,2.3\}$ & $\{0.5,1.0,2.3\}$ \\
\hline \hline
\end{tabular}


Table 9: Targeted Moments

Informality and Home Production Experiments

\begin{tabular}{lcccc}
\hline Moments & Data & $\begin{array}{c}\text { Formality } \\
\text { Home } \\
\text { Production }\end{array}$ & $\begin{array}{c}\text { Formality }+ \\
\text { Informality }\end{array}$ & $\begin{array}{c}\text { Only } \\
\text { Formality }\end{array}$ \\
\hline \hline Capital to output ratio & 1.678 & 1.666 & 1.695 & 1.700 \\
$\begin{array}{l}\text { Aggregate hours worked } \\
\text { Fraction of GNP spent on }\end{array}$ & 0.495 & 0.498 & 0.495 & 0.496 \\
$\begin{array}{l}\text { social programs } \\
\begin{array}{l}\text { Fraction of labor income } \\
\text { earned by manual laborers }\end{array}\end{array}$ & 0.144 & 0.142 & 0.143 & 0.142 \\
$\begin{array}{l}\text { Fraction of labor income } \\
\text { earned by employees }\end{array}$ & 0.520 & 0.267 & 0.292 & 0.291 \\
$\begin{array}{l}\text { Fraction of labor income } \\
\text { earned by managers }\end{array}$ & 0.270 & 0.507 & 0.518 & 0.516 \\
\hline \hline
\end{tabular}

Table 10: Impact of Informality and Home Production on Long-Run Welfare Gains

\begin{tabular}{ccccc}
\hline & Baseline & $\begin{array}{c}\text { Formality } \\
\text { Home } \\
\text { Production }\end{array}$ & $\begin{array}{c}\text { Formality }+ \\
\text { Informality }\end{array}$ & $\begin{array}{c}\text { Only } \\
\text { Formality }\end{array}$ \\
\hline \hline Total & 11.1 & 10.8 & 3.9 & 4.2 \\
\hline $\begin{array}{c}\text { Manual } \\
\text { Laborers }\end{array}$ & 6.8 & 5.6 & 2.3 & 2.2 \\
Employees & 15.2 & 15.6 & 5.4 & 6.1 \\
Managers & 16.2 & 16.9 & 5.4 & 6.1 \\
\hline
\end{tabular}

